\title{
Article \\ Lignocellulolytic Potential of the Recently Described Species Aspergillus olivimuriae on Different Solid Wastes
}

\author{
Eleonora Carota ${ }^{+}{ }^{-}$, Silvia Crognale ${ }^{\dagger}$, Cristina Russo ${ }^{(0)}$, Maurizio Petruccioli and Alessandro D’Annibale *(D) \\ Department for Innovation in Biological Agro-Food and Forest Systems (DIBAF), University of Tuscia, Via S. \\ Camillo De Lellis snc, 01100 Viterbo, Italy; carota@unitus.it (E.C.); crognale@unitus.it (S.C.); \\ cristina.russo@hotmail.it (C.R.); petrucci@unitus.it (M.P.) \\ * Correspondence: dannib@unitus.it \\ + E.C. and S.C. contributed equally to this work.
}

Citation: Carota, E.; Crognale, S.; Russo, C.; Petruccioli, M.; D'Annibale, A. Lignocellulolytic Potential of the Recently Described Species Aspergillus olivimuriae on Different Solid Wastes. Appl. Sci. 2021, 11, 5349 https://doi.org/10.3390/app11125349

Academic Editor: Antonio Valero

Received: 6 May 2021

Accepted: 7 June 2021

Published: 9 June 2021

Publisher's Note: MDPI stays neutral with regard to jurisdictional claims in published maps and institutional affiliations.

Copyright: (c) 2021 by the authors. Licensee MDPI, Basel, Switzerland. This article is an open access article distributed under the terms and conditions of the Creative Commons Attribution (CC BY) license (https:// creativecommons.org/licenses/by/ $4.0 /)$

\begin{abstract}
The genus Aspergillus encompasses several species with relevant lignocellulose-degrading capacity, and a novel species, denominated A. olivimuriae, was recently discovered after its isolation from table olive brine. The acquisition of insight into this species and the assessment of its potential relied on a bioinformatics approach, based on the CAZy database, associated with enzymatic activity profiles in solid-state cultures on four different types of waste, including residual thistle biomass (RTB), spent coffee grounds (SCG), digestate solid fraction and barley straw. The CAZy analysis of $A$. olivimuriae genome showed that the number of predicted genes for each family was close to that of other Aspergillus species, except for cellobiose dehydrogenase, acetyl xylan esterase and polygalacturonases. In A. olivimuriae solid-state cultures, hemicellulose degradation outperformed that of cellulose, and lignin removal did not occur, regardless of the growth substrate. This is in line with its CAZy content and the extent of hemicellulolytic, and ligninolytic activities detected in its solid-state cultures. RTB and barley straw were the substrates enabling the best glycosyl hydrolase production levels. The exception was SCG, the hemicellulose composition of which, mainly made of glucomannans and galactomanans, led to the highest $\beta$-mannanase and $\beta$-mannosidase production levels (3.72 \pm 0.20 and $0.90 \pm 0.04 \mathrm{IU} \mathrm{g}^{-1}$ substrate, respectively).
\end{abstract}

Keywords: Aspergillus olivimuriae; solid-state fermentation; wastes; supply chains; glycosyl hydrolases; CAZyme annotation

\section{Introduction}

The characterization of new isolates and strains from public culture collections is essential for knowledge implementation and to provide the research and biotechnological industry with helpful information for conducting screenings to find microbial strains of potential interest. There is a global abundance of lignocellulosic residues, for instance, lignocellulolytic fungi are acquiring an ever-increasing role in biorefinery-based applications aiming to upgrade biomass through the production of value-added products [1]. Owing to the structural heterogeneity and complexity that characterize plant biomass, fungi need to produce a wide set of glycosyl hydrolase activities to perform the breakdown of plant polysaccharides into their monomeric constituents [2,3]. The Carbohydrate-Active EnZyme database (CAZy; http:/ / www.cazy.org; accessed on 8 June 2021) has divided these enzymes into families, based on the catalytic modules in their respective amino acid sequence. Several studies suggest that this database might be a robust tool, affording insights into the carbohydrate-degrading aptitude of a given fungal species and supporting the classification and functional prediction of novel genes $[2,4,5]$. The CAZy database also enables predicting Auxiliary Activity (AA) families involving lignin-modifying enzymes such as laccases (AA1) and ligninolytic peroxidases (lignin peroxidase, manganese peroxidases and versatile peroxidases) (AA2) [6]. 
Several members belonging to the Aspergillus genus have a widely recognized capacity to degrade lignocellulose $[1,2]$ and, in the last two decades, a growing number of studies have reported on the presence of lignin-modifying enzymes in Aspergillus species [7,8].

In recent decades, the significant advances in molecular taxonomy have enabled the discovery of an ever-increasing number of species belonging to the Aspergillus genus $[9,10]$, and extreme habitats have offered interesting isolation niches [11,12]. Recently, table olive brine, a liquid matrix commonly hosting lactic acid bacteria and yeast species capable of tolerating high salinity, offered the opportunity to isolate a new species which, due to the isolation source, was denominated A. olivimuriae [13]. Although its whole genome has been sequenced, and the isolate is available from two public culture collections, NRRL 66783 and CCF 6208, this species' physiological information is still scant.

To fill this information gap, this study used a combination of bioinformatics and physiological approaches to predict and evaluate, at different levels, the lignocellulosedegrading potential of $A$. olivimuriae. Since most of the biochemical characterization of members of the CAZy families relies on synthetic (model) substrates [5], the use of complex lignocellulosic matrices might be useful to characterize the enzymatic potential of fungi, considering the large variability in the substrate specificity of polysaccharidedegrading enzymes.

Consequently, the profiles of the glycosyl hydrolases and lignin-modifying enzyme activities of A. olivimuriae were determined in solid-state fermentation, a culture technique that simulates the conditions that saprophytic organisms encounter in nature. These fermentations were carried out on waste from different supply chains, including residual thistle biomass (RTB), spent coffee grounds (SCG), digestate solid fraction (DSF) of anaerobic bioconversions and barley straw. These matrices share the presence of a significant fraction of macromolecules of the plant cell wall (cellulose, hemicellulose and lignin), a characteristic that makes these matrices ideal growth substrates for the expression of enzymes involved in the degradation of these polymers [14,15]. The determination of fungal growth on the substrates under study and the chemical composition changes in the colonized growth substrates offered the necessary integration between genomic and enzymatic analyses.

\section{Materials and Methods}

\subsection{Microorganism and Materials}

The fungal strain used in the present study was Aspergillus olivimuriae 6C2 (NRRL 66783). The strain was maintained and routinely sub-cultured every month on Malt Extract Agar (MEA) slants. The waste residues used in this work, from four different supply chains, were: residual thistle biomass (RTB), spent coffee grounds (SCG), digestate solid fraction (DSF), and barley straw. Expressly, SCG, kindly provided by Prof. Andrea Colantoni (University of Tuscia, Viterbo, Italy), came from the Gedap company (Viterbo, Italy), which deals with automatic coffee distribution. DSF derived from an anaerobic digestion plant, used for biogas production, located near Perugia. RTB, coming from the biorefinery of Porto Torres (Sassari, Italy), is represented by the calathide-deprived epiphytic biomass, from whose seeds the Novamont company extracts dicarboxylic acids used in the production of plasticizers. The barley straw was a kind gift from a farm located in the municipality of Gallese (Viterbo, Italy).

\subsection{Annotation of Protein-Coding Genes for Holocellulose Degrading Enzymes}

To ascertain the presence of putatively coding genes for carbohydrate-active enzymes (CAZymes) and ligninolytic ones, the genome of A. olivimuriae 6C2 (Accession number PRJNA498048) was annotated through the dbCAN2 meta-server (http://bcb.unl.edu/ dbCAN2/; accessed on 8 June 2021) which integrates three tools for the annotation of all CAZymes of a genome: (i) HMMER search against the annotated CAZyme domain boundaries according to the dbCAN HMM (hidden Markov model) database (E-value $<1 \mathrm{e}^{-15}$ and coverage > 0.35); (ii) DIAMOND search for blast hits in the CAZy pre-annotated CAZyme 
sequence database (E-value $<1.0 \times 10^{-102}$ ); (iii) Hotpep search for short conserved motifs against the conserved CAZyme short peptide database (hits $>6$ and the sum of conserved peptide frequencies $>2.6$ ). The three outputs were combined, and the CAZymes found by only one tool were removed to improve the CAZome annotation accuracy [16]. The output generated by the dbCAN2 meta-server is shown in the Supplementary Materials titled "S1_dbCAN2_output_file_A_olivimuriae". Moreover, to avoid misannotated genes a supplementary manual annotation was carried out, as described by Segato et al. [17]. The Supplementary Materials titled "S2_Annotations" contains the details related to the manual annotation.

\subsection{Inoculum Preparation}

Six agar plugs $(\sim 7 \mathrm{~mm} \varnothing)$ from 7-d-old cultures on MEA were transferred into $500-\mathrm{cm}^{3}$ Erlenmeyer flasks containing $100 \mathrm{~cm}^{3}$ of autoclave-sterilized $(394.14 \mathrm{~K}, 15 \mathrm{~min})$ malt extract broth (Oxoid, Basingstoke, UK) and then incubated at $301.15 \mathrm{~K}$ under orbital shaking $(2.5 \mathrm{~Hz})$ for $72 \mathrm{~h}$. The mycelium was recovered by centrifugation at $277.15 \mathrm{~K}(6000 \times g$, $15 \mathrm{~min}$ ), and the pellet thus obtained suspended in physiological solution. The resulting suspension was then homogenized with an Ultra-Turrax T-18 (IKA Labortechnik, Staufen, Germany) at $50 \mathrm{~Hz}$ for $6 \mathrm{~s}$.

\subsection{Solid-State Cultures}

Each substrate $(20 \mathrm{~g})$ was transferred into a $500-\mathrm{cm}^{3}$ Erlenmeyer flask, and its moisture content adjusted to a mass fraction $\left(w_{m}\right)$ of 0.70 using the Mandels and Sternberg's medium (MSM), except for SCG, the moisture content of which was adjusted to a $w_{m}$ equal to 0.55 . The composition of MSM was $\left(\mathrm{g} \mathrm{dm}^{-3}\right)$ : peptone, 1.0; $\left(\mathrm{NH}_{4}\right)_{2} \mathrm{SO}_{4}, 1.4 ; \mathrm{KH}_{2} \mathrm{PO}_{4}, 2.0$, urea, $0.3 ; \mathrm{CaCl}_{2} ; \mathrm{MgSO}_{4} \bullet 7 \mathrm{H}_{2} \mathrm{O}, 0.3 ; \mathrm{FeSO}_{4} \bullet 7 \mathrm{H}_{2} \mathrm{O}, 0.005 ; \mathrm{MnSO}_{4} \bullet \mathrm{H}_{2} \mathrm{O}, 0.002 ; \mathrm{ZnSO}_{4} \bullet 7 \mathrm{H}_{2} \mathrm{O}$, 0.001 , and $\mathrm{COCl}_{2}, 0.002$. Moreover, an additional set of amended cultures was prepared by adding wheat bran (WB) to each substrate to yield a mass fraction $\left(w_{W B}\right)$ equal to 0.20 . Each non-amended and amended culture was inoculated with the homogenized inoculum $\left(5 \mathrm{~cm}^{3}\right)$ to yield an inoculum density of $4.5 \times 10^{-3} \mathrm{~g}$ mycelium $\mathrm{g}^{-1}$ of solid substrate and incubated in the dark at $301.15 \mathrm{~K}$ for $14 \mathrm{~d}$ under stationary conditions. For each amended and non-amended culture, a non-inoculated control was prepared and incubated as above. Each experiment was performed in duplicate.

\subsection{Analytical Methods}

Before chemical analyses, all the materials underwent grinding on a Cyclotec 1093 mill (Foss Analytics, Hilleroed, Denmark) endowed with a 1-mm sieve to make their granulometry uniform. The determination of the crude lipids was carried out gravimetrically after extracting the solid culture samples and the relative incubation controls $(3.0 \mathrm{~g})$ in the Büchi B-811 automated Soxhlet apparatus (Uster, Switzerland) with petroleum ether (boiling range 313-333 K) for $6 \mathrm{~h}$, as described by Cruz et al. [18]. Neutral detergent fibre (NDF), acid detergent fibre (ADF) and acid detergent lignin (ADL) were determined on defatted samples in a Fibertec System M 1020 Tecator (Foss Analytics, Hilleroed, Denmark) using the method of Van Soest et al. [19]. Hemicellulose was calculated as NDF-ADF and cellulose as ADF-ADL [20], while the ash content in ADL was subtracted from ADL to calculate Klason lignin. Total phenols were determined both on the liquid derived from the hydraulic pressing of solid-state cultures and the resulting residual solid. In the latter case, the material underwent extraction for $4 \mathrm{~h}$ at $323 \mathrm{~K}$ with a water:methanol mixture, at a volume fraction of 0.50 , using a solid:liquid ratio of $0.1 \mathrm{~g} \mathrm{~cm}^{-3}$, before being analyzed with the procedure of Ainsworth and Gillespie [21], using catechol as the standard. The determination of reducing sugars relied on a 3,5-dinitrosalicylic acid reagent [22]. The elemental analyzer for solids Vario MacroCube of Elementar Gmbh (Langelselbold, Germany) enabled the determination of the percentage contents in carbon, hydrogen, nitrogen and sulfur and the calibration of the measurements relied on sulfonamide, used as the standard. The ash content was determined after the ignition of samples in a muffle furnace at $823 \mathrm{~K}$ 
for $8 \mathrm{~h}$. The calculation of the organic matter losses (OML, \%) relied on the variations in the ash content recorded in the solid phase cultures $\left(x_{s s c}\right)$ compared to the respective incubation controls $\left(x_{i c}\right)$ according to Equation (1), suggested by Paredes et al. [23]

$$
\operatorname{OML}(\%)=100-\left[\frac{x_{i c} \times\left(100-x_{s s c}\right)}{x_{s s c} \times\left(100-x_{i c}\right)} \times 100\right]
$$

The degree of colonization in solid-state cultures was inferred from both visual inspections and indirectly through a fungal-specific marker represented by $\mathrm{D}$, a fungal wall polymers component. In particular, acid hydrolysis and deacetylation of the colonized material relied on the procedure described by Scotti et al. [24], except for the extract's neutralization step, which used solid sodium carbonate. D-glucosamine was spectrophotometrically determined at $530 \mathrm{~nm}$, as reported elsewhere [25]. The same approach was applied to incubation controls to assess the possible presence of D-glucosamine in solid substrates. Soluble protein was determined in the crude extracts derived from the hydraulic pressing of both solid-state cultures and respective incubation controls by the dye-binding method, using bovine serum albumin as the standard [26]. Soluble protein contents in incubation controls were subtracted from those found in the respective solid-state cultures.

\subsection{Recovery of the Enzymatic Extract from Solid-State Cultures}

At the end of the incubation, $50 \mathrm{~cm}^{3}$ of sodium acetate buffer $\left(0.01 \mathrm{~mol} \mathrm{dm}{ }^{-3}\right)$ at $\mathrm{pH} 5.0$ were added to each culture, and the system was incubated under orbital shaking $(3.0 \mathrm{~Hz})$ for $20 \mathrm{~min}$ on ice. Except for cultures on spent coffee grounds, in which centrifugation at $277.15 \mathrm{~K}(8000 \times g, 20 \mathrm{~min})$ followed the contact time, the other biomasses were subjected to hydraulic pressing to extract the extracellular enzymes. For this purpose, the material was loaded into an extraction cell $(15 \mathrm{~cm} \times 4.0 \mathrm{~cm}$ i.d. $)$, and fluids were extracted at $0.68 \mathrm{MPa}$ and $277.15 \mathrm{~K}$ using a PS-10 press (Ravaglioli, Bologna, Italy). Following extraction, all the extracts underwent sequential filtration through Whatman paper $\mathrm{n} .41$ and centrifugation at $277.15 \mathrm{~K}(8000 \times g, 20 \mathrm{~min})$. The alcohol dehydrogenase activity was measured on the obtained extracts as a cytoplasmic marker to verify possible hyphal damage under the extraction conditions, as reported elsewhere [27].

\subsection{Enzymatic Assays}

Filter Paper Units (FPU) and endo- $\beta-1,4$-glucanase were determined by the method of Ghose [28] using Whatman n. 1 paper and $10 \mathrm{~g} \mathrm{dm}^{-3}$ carboxymethylcellulose (CMC) solution in sodium acetate buffer $\left(0.05 \mathrm{~mol} \mathrm{dm}^{-3}\right)$ at $\mathrm{pH} 5.0$, respectively. At the end of the incubation at $323.15 \mathrm{~K}, 30 \mathrm{~min}$ and $60 \mathrm{~min}$ for the former and the latter substrate, Miller's method [22] determined released the reducing sugars. Cellobiohydrolase, endo$\beta-1,4$-xylanase and $\beta$-mannanase activities were determined by incubating appropriate volumes of extracts in $10 \mathrm{~g} \mathrm{dm}^{-3}$ Avicel, $3.0 \mathrm{~g} \mathrm{dm}^{-3}$, birchwood xylan and $5.0 \mathrm{~g} \mathrm{dm}^{-3}$ carob galactomannan solutions at $323.15 \mathrm{~K}$ for $30 \mathrm{~min}$, in $0.05 \mathrm{~mol} \mathrm{dm}^{-3}$ sodium acetate buffer $\mathrm{pH}$ 5.0, respectively, and determining the amounts of liberated reducing sugars [29]. $\beta$-glucosidase, $\beta$-xylosidase and $\beta$-mannosidase activities were determined by the method of Meijer et al. [30], except for the volume of the reaction mixtures $\left(1.0 \mathrm{~cm}^{3}\right.$ in place of $0.1 \mathrm{~cm}^{3}$ ) and incubation times, which varied in this study between (15 and 30) $\mathrm{min}$. Polymethylgalacturonase (PMG) and polygalacturonase (PG) activities were determined as described by the method of Heerd et al. [31]. Pectinesterase activity was determined by the method of Vilariño et al. (1993) [32]. Laccase and Mn-peroxidase activities were determined using a modification of the method of del Pilar Castillo et al. [33]. The assay relies on the oxidative coupling of 3-methyl-2-benzothiazolinone hydrazone (MBTH) and 3-(dimethylamino)benzoic acid (DMAB) promoted by some phenoloxidizing enzymes, leading to a purple chromophore which strongly absorbs in the red region. The reaction mixture used to determine laccase activity contained $7.0 \times 10^{-5} \mathrm{~mol} \mathrm{dm}^{-3} \mathrm{MBTH}$ and $1.0 \times 10^{-3} \mathrm{~mol} \mathrm{dm}^{-3} \mathrm{DMAB}$ in malonate buffer $\left(0.05 \mathrm{~mol} \mathrm{dm}^{-3}\right) \mathrm{pH} 5.0$ and an adequate volume of extract. In the peroxidase assay, the same mixture contained hydrogen peroxide 
at a final concentration equal to $2.0 \times 10^{-4} \mathrm{~mol} \mathrm{dm}^{-3}$. The absorbance at $590 \mathrm{~nm}$ of the reaction mixture was measured immediately downstream of the addition of the enzyme and after predetermined periods of incubation at $323.15 \mathrm{~K}$ by calculating the variation in optical density per minute (ODM), and data were converted using an extinction coefficient molar equal to $53,000 \mathrm{dm}^{3} \mathrm{~mol}^{-1} \mathrm{~cm}^{-1}$. The peroxidase activity was calculated by subtracting the ODM in the laccase mixture from that measured in the presence of $\mathrm{H}_{2} \mathrm{O}_{2}$. Regardless of the assay, incubation controls were run in parallel with heat-denatured extracts. Volumetric activities, originally expressed in International Units (IU), defined as the amount of enzyme releasing $1 \mu$ mole of product per $\mathrm{cm}^{3}$ under the assay conditions, were converted into specific activities, referred to either the unit mass of the solid substrate or soluble protein.

\subsection{Statistical Analysis}

Data were analyzed by one-way ANOVA and post-hoc Tukey test at a significance level of 0.05, using the SigmaStat 3 software (Jandel Corp, San Rafael, CA, USA).

\section{Results and Discussion}

\subsection{Chemical Characterization of the Residues}

The first phase of the work focused on characterizing the chemical composition of the four residues and the wheat bran (WB) used in some solid-state cultures as the additive.

The choice of WB was made due to the inclusion, in this investigation, of spent coffee grounds (SCG), a matrix that, owing to its constituent particles' fine granulometry, has low porosity, making gas exchanges problematic. Due to its coarse texture, wheat bran is well-suited to act as a bulking agent capable of increasing the material's overall porosity. Added to this is the fact that the bran has a relatively high nitrogen content $\left(30.1 \mathrm{~g} \mathrm{~kg}^{-1}\right)$ (Table 1), being mainly composed of protein and amino acids [34]. Furthermore, WB contains microelements and cofactors which are essential for growth, such as B vitamins and folates [35]. Consequently, this study set up and analyzed solid-state cultures on both non-amended and WB-amended residues to make the experimental design homogeneous.

Table 1. Chemical composition of residual thistle biomass (RTB), spent coffee grounds (SCG), digestate solid fraction (DSF), barley straw and wheat bran (WB). The data, expressed as $\mathrm{g} \mathrm{kg}^{-1}$ of the dry weight, are the mean \pm standard deviation of 3 determinations. Multiple pair-wise comparisons were made between the row means using the Tukey test; identical letters denote that row means were not significantly different $(p>0.05)$.

\begin{tabular}{cccccc}
\hline Parameter $\left(\mathbf{g ~ k g}^{-1}\right)$ & RTB & SGC & DSF & Barley Straw & WB + \\
\hline Hemicellulose & $189.2 \pm 3.2 \mathrm{a}$ & $375.2 \pm 16.8 \mathrm{c}$ & $172.2 \pm 14.9 \mathrm{a}$ & $279.3 \pm 3.0 \mathrm{~b}$ & $187.6 \pm 12.2 \mathrm{c}$ \\
Cellulose & $405.9 \pm 12.1 \mathrm{c}$ & $120.2 \pm 3.2 \mathrm{a}$ & $393.4 \pm 24.4 \mathrm{c}$ & $420.6 \pm 2.2 \mathrm{c}$ & $201.1 \pm 24.3 \mathrm{~b}$ \\
Klason lignin & $204.2 \pm 4.6 \mathrm{c}$ & $201.7 \pm 7.2 \mathrm{c}$ & $257.4 \pm 14.2 \mathrm{~d}$ & $165.2 \pm 4.6 \mathrm{~b}$ & $73.2 \pm 3.9 \mathrm{a}$ \\
Crude lipids & $20.8 \pm 1.4 \mathrm{a}$ & $139.8 \pm 5.4 \mathrm{c}$ & $19.3 \pm 2.7 \mathrm{a}$ & $16.2 \pm 1.8 \mathrm{a}$ & $45.4 \pm 4.3 \mathrm{~b}$ \\
Reducing sugars & $3.6 \pm 0.4 \mathrm{a}$ & $4.1 \pm 0.2 \mathrm{a}$ & $9.2 \pm 0.4 \mathrm{~b}$ & $41.8 \pm 2.7 \mathrm{c}$ & $49.3 \pm 3.2 \mathrm{~d}$ \\
Phenols & $17.2 \pm 1.5 \mathrm{~b}$ & $49.2 \pm 2.4 \mathrm{~d}$ & $15.3 \pm 2.4 \mathrm{~b}$ & $21.4 \pm 1.6 \mathrm{c}$ & $9.2 \pm 1.7 \mathrm{a}$ \\
Ash & $85.3 \pm 7.0 \mathrm{~d}$ & $20.4 \pm 2.5 \mathrm{a}$ & $82.1 \pm 3.6 \mathrm{~d}$ & $70.1 \pm 5.3 \mathrm{c}$ & $43.6 \pm 2.1 \mathrm{~b}$ \\
Nitrogen & $5.9 \pm 0.3 \mathrm{a}$ & $22.8 \pm 1.6 \mathrm{c}$ & $19.8 \pm 1.1 \mathrm{~b}$ & $5.4 \pm 0.4 \mathrm{a}$ & $30.1 \pm 1 \mathrm{~d}$ \\
Carbon & $423.4 \pm 8.0 \mathrm{ab}$ & $508.9 \pm 11.1 \mathrm{~d}$ & $415.3 \pm 8.2 \mathrm{a}$ & $467.4 \pm 5.4 \mathrm{c}$ & $441.2 \pm 4.2 \mathrm{~b}$ \\
Hydrogen & $62.1 \pm 2.0 \mathrm{~b}$ & $75.6 \pm 1.8 \mathrm{c}$ & $59.4 \pm 2.1 \mathrm{a}$ & $55.2 \pm 4.1 \mathrm{a}$ & $69.3 \pm 4.2 \mathrm{c}$ \\
Sulphur & $1.7 \pm 0 \mathrm{~b}$ & $1.0 \pm 0 \mathrm{a}$ & $2.2 \pm 0.1 \mathrm{~b}$ & $0.1 \pm 0.0 \mathrm{a}$ & $1.8 \pm 0.0 \mathrm{~b}$ \\
\hline
\end{tabular}

+ Starch, the content of which was $175.4 \mathrm{~g} \mathrm{~kg}^{-1}$ in $\mathrm{WB}$, was omitted in this table since this parameter was not detected in the other waste.

Table 1 shows that the holocellulosic component, determined by the cellulose and hemicellulose contents' aggregation, constituted a significant fraction of the residues under study, since its mass fraction $\left(w_{H C}\right)$ reached values equal to or well above 0.50 of the dry weight. In particular, the highest $w_{H C}$ was found in barley straw, where the aggregate sum of the cellulose and hemicellulose concentrations gave a value equal to about 0.70 , followed by RTB, in which the value of this parameter was slightly less than 0.60 . Cellulose was the dominant polysaccharide in RTB, barley straw and DSF $(405.9 \pm 12.3,420.6 \pm 2.2$ and $395.4 \pm 24 \mathrm{~g} \mathrm{~kg}^{-1}$, respectively). Conversely, SCG exhibited the lowest content of this 
parameter $\left(120.2 \pm 3.2 \mathrm{~g} \mathrm{~kg}^{-1}\right)$, and hemicelluloses were the most abundant polysaccharide fraction $\left(375 \pm 16.8 \mathrm{~g} \mathrm{~kg}^{-1}\right)$. The monomeric composition of the hemicelluloses in this matrix consists mainly of mannose, galactose and, to a lesser extent, arabinose residues forming galactomannans and arabinogalactans [36]. Moreover, xylose polymers are absent from this matrix, and this is a particular element that differentiates SCG from the remaining residues $[36,37]$. In addition to its relatively high hemicellulose content, three additional parameters significantly differentiated SCG from other residues in terms of composition. These were the lower ash content $\left(20.4 \pm 2.5 \mathrm{~g} \mathrm{~kg}^{-1}\right)$ and higher crude lipids $\left(139.8 \pm 5.4 \mathrm{~g} \mathrm{~kg}^{-1}\right)$ and total phenols $\left(49.2 \pm 2.4 \mathrm{~g} \mathrm{~kg}^{-1}\right)$ contents than the other three residues. Crude lipid contents in SCG are very similar to those reported in various studies conducted on this matrix $[18,38,39]$. Concerning the phenolic content in SGC, some studies report concentrations ranging from (17 to 50$) \mathrm{g} \mathrm{kg}^{-1}[18,40]$, and the main components of this fraction fall within the family of chlorogenic acids within which the quantitatively most relevant compound is 5-O-caffeoylquinic acid [39]. Among the matrices investigated, the lowest phenolic content was in wheat bran $\left(9.2 \pm 1.7 \mathrm{~g} \mathrm{~kg}^{-1}\right)$, although it is considered a relevant source of hydroxy-substituted cinnamic acids [41,42]. However, a significant fraction of these aromatic acids is esterified to the side chains of arabinose residues in arabinoxylans [35] and, therefore, not present in its free form in WB.

Regarding other WB composition data, Table 1 shows that its holocellulosic fraction amounted, overall, to around $390 \mathrm{~g} \mathrm{~kg}^{-1}$, in agreement with other works [43,44]. For the same matrix, however, the obtained Klason lignin content $\left(73.2 \pm 3.9 \mathrm{~g} \mathrm{~kg}^{-1}\right)$ was significantly lower than those reported by Merali et al. [44] and Prinsen et al. [45], and equal to (108 and 121) $\mathrm{g} \mathrm{kg}^{-1}$, respectively.

The Klason lignin contents in RTB and SCG were not significantly different from each other, providing values of about $200 \mathrm{~g} \mathrm{~kg}^{-1}$ while, in barley straw, this parameter amounted to $165.2 \pm 2.4 \mathrm{~g} \mathrm{~kg}^{-1}$. This parameter's highest value, equal to $257 \mathrm{~g} \mathrm{~kg}^{-1}$, was found in DSF, since stoned olive pomace represents a significant fraction of the feed biomass to the digester from which this matrix derives.

In SCG, the data relating to the total nitrogen content $\left(22.8 \mathrm{~g} \mathrm{~kg}^{-1}\right)$ and the $\mathrm{C} / \mathrm{N}$ ratio (22.3), determined by elemental analysis, are also in agreement with a survey conducted by Cruz et al. [18] on a large variety of spent coffee grounds. From this perspective, the $\mathrm{C} / \mathrm{N}$ ratios of spent coffee grounds and DSF did not significantly differ. This parameter's highest value, equal to about 86.6, was found in barley straw while, in RTB, it was equal to 71.8 .

\subsection{Fungal Colonization of Solid Substrates and Impact on Their Chemical Composition}

One of the significant constraints inherent in solid-state bioconversions, compared to those in the liquid phase, is represented by the impossibility of directly determining the microbial biomass [46]. Contrary to the submerged fermentation, in which the fungal biomass is easily separated from the culture medium and determined by gravimetry, this approach is not possible in solid-state conversions on natural substrates. Therefore, it is necessary to resort to indirect approaches based on either molecular or chemical markers [46]. The most used chemical "markers" for fungi are ergosterol and D-glucosamine. In the first case, the solid material is subjected to saponification, followed by extraction with n-hexane and quantification of ergosterol by reverse-phase chromatography [20]. The second parameter's determination requires acid hydrolysis of the material, deacetylation, and quantification of the D-glucosamine, released by chromatography or spectrophotometry [24]. However, D-glucosamine levels vary in fungal species in a range of from 67 to $125 \mathrm{mg} \mathrm{g}^{-1}$ of biomass, depending on the culture's species and age $[14,47]$. Although aware that cultivation conditions can also influence this parameter's levels, we adopted D-glucosamine as an indirect indicator of colonization levels, bearing in mind that the comparisons took place within the same fungal species and between cultures of the same age. We also considered the possible presence of D-glucosamine residues which are sometimes associated with glycoproteins in the lignocellulosic substrates [14]. Although this parameter's levels were significantly low 
in the incubation controls, varying in the range of from 0.03 to $0.18 \mathrm{mg} \mathrm{g}^{-1}$ substrate (data not shown), these were subtracted from those determined in solid-state cultures.

Table 2 shows that, among the non-amended cultures, the lowest growth was observed on barley straw, while the colonization levels did not differ significantly from each other in the remaining substrates, ranging from 0.79 to $0.94 \mathrm{mg}$ D-glucosamine $\mathrm{g}^{-1}$ substrate. On the contrary, an element that emerged from the D-glucosamine data analysis was the stimulating effect of WB on fungal growth in the amended cultures compared to non-amended ones except those carried out on DSF. This stimulation effect was of variable magnitude depending on the substrate. In particular, in solid-state cultures on WB-amended barley straw, the colonization levels increased by a factor of more than four compared to non-amended counterparts ( $2.99 \pm 0.5$ vs. $0.70 \pm 0.04 \mathrm{mg}$ D-glucosamine $\left.\mathrm{g}^{-1}\right)$, and visual inspections corroborated the observed data. A loose mycelium with a limited extension to the most peripheral layers of the substrate characterized non-amended cultures on barley straw. Conversely, in WB-amended cultures, the mycelium appeared to be more compact, and the colonization affected the entire substrate mass. In WB-amended cultures on RTB and SCG, the factors of increase in D-glucosamine levels compared to homologous non-amended cultures were equal to 2.2 and 2.7 , respectively.

Table 2. D-glucosamine and extracellular protein (EXP) contents, $\mathrm{pH}$ changes, organic matter losses (OML) and yield of fungal biomass per unit of organic matter consumed $\left(\mathrm{Y}_{\mathrm{GLC} / \mathrm{S}}\right)$ in 14-day-old A. olivimuriae solid-state cultures carried out on residual thistle biomass (RTB), spent coffee grounds (SCG), barley straw (BS) and solid fraction of digestate (SFD) in the presence and in the absence of wheat bran (WB). Data are mean \pm standard deviation of 4 replicates. Multiple pair-wise comparisons were made with Tukey's test, and identical letters denote that column means were not statistically different $(p>0.05)$.

\begin{tabular}{|c|c|c|c|c|c|}
\hline $\begin{array}{l}\text { Solid-State } \\
\text { Cultures On: }\end{array}$ & $\begin{array}{l}\text { D-Glucosamine } \\
\left(\mathrm{mg} \mathrm{g}^{-1}\right)\end{array}$ & $\operatorname{EXP}\left(m g g^{-1}\right)$ & $\Delta \mathrm{pH}+$ & OML $\ddagger(\%)$ & $\mathrm{Y}_{\mathrm{GLC} / \mathrm{S}}\left(\mathrm{mg} \mathrm{g}^{-1}\right)$ \\
\hline RTB & $0.87 \pm 0.05 \mathrm{ab}$ & $2.89 \pm 0.24 b$ & $-0.80(6.93 \pm 0.03)$ & $12.64 \pm 0.40 c$ & $6.88 \pm 0.50 b$ \\
\hline $\mathrm{RTB}+\mathrm{WB}$ & $1.89 \pm 0.07 c$ & $3.49 \pm 0.11 c$ & $-0.56(6.43 \pm 0.04)$ & $17.01 \pm 0.60 \mathrm{e}$ & $11.11 \pm 0.41 \mathrm{c}$ \\
\hline SCG & $0.94 \pm 0.06 \mathrm{~b}$ & $2.00 \pm 0.09 \mathrm{a}$ & $-1.75(5.77 \pm 0.04)$ & $10.77 \pm 1.21 \mathrm{~b}$ & $8.73 \pm 0.46 b$ \\
\hline$S C G+W B$ & $2.47 \pm 0.08 \mathrm{~d}$ & $1.89 \pm 0.12 \mathrm{a}$ & $-0.73(5.34 \pm 0.02)$ & $14.70 \pm 0.81 \mathrm{~d}$ & $16.80 \pm 0.54 \mathrm{~d}$ \\
\hline BS & $0.70 \pm 0.06 \mathrm{a}$ & $5.46 \pm 0.33 \mathrm{~d}$ & n.s. ${ }^{*}(6.50 \pm 0.04)$ & $8.43 \pm 0.34 \mathrm{a}$ & $8.30 \pm 1.30 \mathrm{~b}$ \\
\hline $\mathrm{BS}+\mathrm{WB}$ & $2.99 \pm 0.21 \mathrm{e}$ & $5.04 \pm 0.18 \mathrm{~d}$ & $-0.17(6.83 \pm 0.02)$ & $12.24 \pm 0.78 \mathrm{bc}$ & $24.44 \pm 1.63 \mathrm{e}$ \\
\hline DSF & $0.79 \pm 0.04 \mathrm{ab}$ & $3.68 \pm 0.07 c$ & $+0.24(6.60 \pm 0.05)$ & $17.73 \pm 0.51 \mathrm{e}$ & $4.46 \pm 0.49 \mathrm{a}$ \\
\hline $\mathrm{DSF}+\mathrm{WB}$ & $0.87 \pm 0.03 \mathrm{ab}$ & $3.70 \pm 0.38 c$ & $+0.64(6.92 \pm 0.08)$ & $17.03 \pm 0.46 \mathrm{e}$ & $5.11 \pm 0.7 \mathrm{ab}$ \\
\hline
\end{tabular}

$(\dagger)$ The data in round brackets are the $\mathrm{pH}$ values found in the non-inoculated incubation controls; $(\ddagger)$ calculated from the ash content in solid-state cultures and related incubation controls using the equation of Paredes et al. (2002); ${ }^{*}$ n. s., not significant ( $\mathrm{pH}$ values of solid-state cultures did not significantly differ from the respective incubation controls).

In A. olivimuriae solid-state cultures, colonization led, compared to incubation controls, to the slight acidification of some matrices, such as in RTB ( $6.13 \pm 0.02$ vs. $6.93 \pm 0.03)$ and, to a greater extent, in SCG (4.02 \pm 0.05 vs. $5.77 \pm 0.04)$, and this effect was also observed in the respective WB-amended cultures. In those carried out on barley straw, the $\mathrm{pH}$ values did not differ significantly from those of the relative incubation control while, on the WB-amended ones, slight acidification took place ( $6.66 \pm 0.02$ vs. $6.88 \pm 0.01)$. Although not experimentally demonstrated, the acidification observed in solid-state cultures was presumably due to the production of organic acids, a general metabolic characteristic among the species belonging to the Aspergillus genus that can lead to the substrate $\mathrm{pH}$ being lowered by four units $[14,48,49]$.

The production of organic acids by these species seems to be a strategy implemented in nature to counteract the antagonistic effect exerted by bacteria [50]. Conversely, on the DSF, the solid-state cultures' pH values were higher than those of the incubation controls, albeit with limited variations. The lack of acidification on this matrix may be due to the known buffering capacity of the digestate [51].

Table 2 also shows the biotic losses of organic matter are attributable to mineralization and calculated based on the ash contents of the solid-phase cultures and the related 
incubation controls. The amendment's presence increased the extents of organic matter losses in thistle biomass, barley straw and SCG. Conversely, this parameter's values did not significantly differ in non-amended and amended cultures on DSF $(17.73 \pm 0.51$ and $17.03 \pm 0.46$, respectively). The values of the biomass yields $\left(\mathrm{Y}_{\mathrm{GLC} / \mathrm{S}}\right)$, derived by relating D-glucosamine levels to the unit mass of organic matter consumed, did not significantly differ in non-supplemented cultures, while the presence of the WB markedly increased this parameter in amended ones.

Table 3 shows the contents in cellulose, hemicellulose, lignin, reducing sugars, crude lipids and total phenols in the incubation controls and the respective cultures inoculated with A. olivimuriae. ANOVA was conducted on four homogeneous blocks represented by each substrate to verify the significance of the differences between each parameter's values in the cultures and the incubation controls in both the amended and non-amended cultures. Regarding the changes induced by the fungus on the cell wall polysaccharide contents, the percentage removal values of the hemicelluloses were significantly higher than those of cellulose, with the only exception being represented by cultures grown on WBamended RTB; under these conditions, cellulose removal significantly increased compared to homologous non-amended cultures ( $23.5 \mathrm{vs.} 12.7 \%$ ). The percentage of hemicellulose removal varied widely, ranging from $12 \%$ in cultures grown on SCG to $59.7 \%$ in nonamended DSF ones. WB's general effect in amended cultures was to determine an increase in wall polysaccharides' removal levels compared to those observed in non-amended ones. RTB and DSF were exceptions to this rule, since non-amended cultures outperformed amended ones in hemicellulose removals ( 34 vs. $26.7 \%$ and 59.7 vs. $47.6 \%$, respectively). The presence of WB generally improved the cellulose removal in the amended cultures, even though, in some cases, the extents of these increases were slight. In general, this study observed a higher susceptibility of hemicelluloses to degradation than cellulose, regardless of the substrate and presence or absence of $\mathrm{WB}$. These results are in line with several studies which ascribe the higher recalcitrance of cellulose to biodegradation rather than hemicellulose, due to its partial crystallinity [14,52].

The increase in reducing sugars observed on solid-state cultures on RTB and SCG, compared to the respective incubation controls, testifies to the partial degradation of the structural polysaccharides, although the concentrations of reducing sugars are the result of the balance between the hydrolysis of the polymers themselves and fungal uptake of the monosaccharides made available by the hydrolysis itself. In these cultures, comparing the yield in reducing sugars released by the hydrolysis of cellulose and hemicelluloses and those found in the extracts, it is evident that A. olivimuriae metabolized a high fraction of these (data not shown).

Table 3 shows that, with few exceptions, the Klason lignin contents in the cultures did not differ significantly from their respective incubation controls, apparently suggesting that $A$. olivimuriae does not have ligninolytic aptitudes, as was widely thought for several years for most Aspergillus species [53]. Some studies, conducted in solid-state fermentation and simultaneous saccharification and fermentation with other organisms, suggest that the preferential degradation of cellulose and hemicellulose inevitably leads to a shift in the relative percentage proportions of the wall macromolecules, thus leading to a lignin-enriched residue [20,54]. For this reason, some studies have proposed normalizing the lignin mass fractions to their respective ash contents $[20,23]$. However, even after this normalization, no significant lignin removal was evident in A. olivimuriae solid-state cultures. In this respect, this species differs from other Aspergilli, such as A. oryzae [8] and A. flavus [55], which have shown ligninolytic potential.

Except for the non-amended cultures grown on DSF and barley straw, total phenol concentrations were significantly higher than those of the respective incubation controls. To explain these results, we could hypothesize the hydrolysis of glucosides by $\beta$-glucosidase, leading to the release of phenolic aglycones. Alternatively, we might invoke a partial lignin fragmentation, not translating into a substantial decrease in this parameter but leading to 
the liberation of phenolic hydroxyls or the release of hydroxycinnamic acids from WB in amended cultures due to the action of A. olivimuriae feruloyl esterase.

Table 3. Contents of cellulose, hemicellulose, Klason lignin, reducing sugars, total phenols and crude lipids in noninoculated incubation controls (IC) and 14-day-old A. olivimuriae solid-state cultures (SSC) on residual thistle biomass (RTB), spent coffee grounds (SCG), barley straw (BS) and digestate solid fraction (DSF) in the absence and in the presence of wheat bran (WB). Data represent the mean \pm standard deviation of 4 replicates. Multiple pairwise comparisons were carried out within each matrix using the Tukey test, and identical letters denote that column means within each block were not significantly different $(p>0.05)$.

\begin{tabular}{|c|c|c|c|c|c|c|}
\hline Culture & $\begin{array}{l}\text { Cellulose } \\
\left(\mathrm{g} \mathrm{kg}^{-1}\right)\end{array}$ & $\begin{array}{l}\text { Hemicellulose } \\
\qquad\left(\mathrm{g} \mathrm{kg}^{-1}\right)\end{array}$ & $\begin{array}{l}\text { Klason Lignin } \\
\quad\left(\mathrm{g} \mathrm{kg}^{-1}\right)\end{array}$ & $\begin{array}{l}\text { Reducing Sugars } \\
\qquad\left(\mathrm{g} \mathrm{kg}^{-1}\right)\end{array}$ & $\begin{array}{l}\text { Crude Lipids } \\
\quad\left(\mathrm{g} \mathrm{kg}^{-1}\right)\end{array}$ & $\begin{array}{l}\text { Total Phenols } \\
\quad\left(\mathrm{g} \mathrm{kg}^{-1}\right)\end{array}$ \\
\hline RTB (IC) & $405.6 \pm 12.1 c$ & $187.0 \pm 3.3 c$ & $201.1 \pm 8.0 \mathrm{a}$ & $3.3 \pm 0.6 \mathrm{a}$ & $20.9 \pm 2.0 \mathrm{~b}$ & $17.3 \pm 2.3 \mathrm{a}$ \\
\hline RTB (SSC) & $354.2 \pm 4.0 \mathrm{~b}$ & $121.9 \pm 4.4 \mathrm{a}$ & $217.5 \pm 2.2 \mathrm{a}$ & $17.7 \pm 2.2 b$ & $14.5 \pm 1.3 \mathrm{a}$ & $38.3 \pm 4.2 c$ \\
\hline RTB + WB (IC) & $365.6 \pm 13.4 b$ & $167.7 \pm 6.2 \mathrm{~b}$ & $181.2 \pm 14.4 \mathrm{a}$ & $3.7 \pm 0.5 \mathrm{a}$ & $26.5 \pm 2.1 c$ & $15.6 \pm 3.4 \mathrm{a}$ \\
\hline RTB + WB (SSC) & $279.6 \pm 16.3 \mathrm{a}$ & $123.4 \pm 12.1 \mathrm{a}$ & $204.8 \pm 19.5 \mathrm{a}$ & $16.4 \pm 0.6 \mathrm{~b}$ & $15.3 \pm 3.2 \mathrm{a}$ & $23.8 \pm 2.8 \mathrm{~b}$ \\
\hline SCG (IC) & $119.2 \pm 3.0 \mathrm{~b}$ & $370.2 \pm 16.3 c$ & $199.4 \pm 18.5 b$ & $3.2 \pm 0.0 \mathrm{a}$ & $139.0 \pm 6.4 c$ & $48.7 \pm 3.2 b$ \\
\hline SCG (SSC) & $105.4 \pm 4.4 \mathrm{a}$ & $326.3 \pm 18.3 b$ & $240.0 \pm 21.3 c$ & $7.6 \pm 1.1 \mathrm{~b}$ & $109.2 \pm 4.1 \mathrm{~b}$ & $56.0 \pm 2.3 c$ \\
\hline $\mathrm{SCG}+\mathrm{WB}(\mathrm{IC})$ & $136.2 \pm 3.2 c$ & $337.1 \pm 8.6$ bc & $171.4 \pm 5.2 \mathrm{a}$ & $3.1 \pm 0.5 \mathrm{a}$ & $121.2 \pm 8.2 \mathrm{~b}$ & $40.8 \pm 2.1 \mathrm{a}$ \\
\hline $\mathrm{SCG}+\mathrm{CG}(\mathrm{SSC})$ & $103.5 \pm 3.1 \mathrm{a}$ & $255.4 \pm 21.6 \mathrm{a}$ & $176.5 \pm 5.2 \mathrm{ab}$ & $9.6 \pm 0.4 c$ & $75.8 \pm 10.3 \mathrm{a}$ & $51.5 \pm 2.6 \mathrm{bc}$ \\
\hline BS (IC) & $420.1 \pm 3.0 \mathrm{~d}$ & $279.5 \pm 11.2 c$ & $165.0 \pm 14.3 \mathrm{a}$ & $41.3 \pm 2.8 \mathrm{a}$ & $15.6 \pm 1.1 \mathrm{a}$ & $20.7 \pm 2.1 \mathrm{ab}$ \\
\hline BS (SSC) & $393.9 \pm 3.2 c$ & $237.0 \pm 9.3 \mathrm{~b}$ & $172.6 \pm 8.2 \mathrm{a}$ & $51.3 \pm 2.0 \mathrm{~b}$ & $12.0 \pm 1.9 \mathrm{a}$ & $27.1 \pm 4.3 \mathrm{~b}$ \\
\hline $\mathrm{BS}+\mathrm{WB}(\mathrm{IC})$ & $376.1 \pm 8.3 b$ & $262.7 \pm 8.3 c$ & $159.0 \pm 14.8 \mathrm{a}$ & $43.4 \pm 4.6 \mathrm{a}$ & $21.4 \pm 2.4 b$ & $18.4 \pm 4.2 \mathrm{a}$ \\
\hline $\mathrm{BS}+\mathrm{WB}(\mathrm{SSC})$ & $339.7 \pm 5.0 \mathrm{a}$ & $210.4 \pm 7.6 \mathrm{a}$ & $170.6 \pm 13.3 \mathrm{a}$ & $40.8 \pm 5.4 \mathrm{a}$ & $20.3 \pm 3.0 \mathrm{~b}$ & $25.4 \pm 3.0 \mathrm{~b}$ \\
\hline DSF (IC) & $393.2 \pm 4.6 \mathrm{c}$ & $174.1 \pm 12.3 \mathrm{c}$ & $257.2 \pm 11.6 \mathrm{bc}$ & $10.9 \pm 0.5 \mathrm{~b}$ & $19.2 \pm 3.1 \mathrm{~b}$ & $15.6 \pm 1.6 \mathrm{~b}$ \\
\hline DSF (SSC) & $363.0 \pm 7.1 \mathrm{~b}$ & $70.2 \pm 9.1 \mathrm{a}$ & $272.0 \pm 8.3 c$ & $4.6 \pm 0.3 \mathrm{a}$ & $21.4 \pm 0.2 \mathrm{~b}$ & $11.9 \pm 2.0 \mathrm{a}$ \\
\hline $\mathrm{DSF}+\mathrm{WB}(\mathrm{IC})$ & $354.2 \pm 4.1 \mathrm{~b}$ & $177.3 \pm 8.6 \mathrm{c}$ & $220.3 \pm 4.8 \mathrm{a}$ & $17.4 \pm 3.1 \mathrm{c}$ & $22.4 \pm 3.1 \mathrm{~b}$ & $14.3 \pm 1.3 \mathrm{ab}$ \\
\hline $\mathrm{DSF}+\mathrm{WB}(\mathrm{SSC})$ & $321.3 \pm 12.0 \mathrm{a}$ & $92.7 \pm 8.3 b$ & $236.1 \pm 5.2 \mathrm{~b}$ & $4.9 \pm 0.1 \mathrm{a}$ & $4.4 \pm 0.2 \mathrm{a}$ & $12.9 \pm 1.1 \mathrm{a}$ \\
\hline
\end{tabular}

Crude lipids were minor components in RTB, barley straw, and DSF, reaching values in the incubation controls lower or slightly higher than $20 \mathrm{~g} \mathrm{~kg}^{-1}$. The only exceptions were represented by the uncorrected and amended SCG incubation controls, where this parameter amounted to around (139 and 121) $\mathrm{g} \mathrm{kg}^{-1}$, undergoing a reduction of 24 and $37.3 \%$, respectively, in solid-state cultures.

\subsection{Gene Prediction of Holocellulose Degrading Enzymes in A. olivimuriae}

Genomes of Aspergillus species code for a high number of CAZymes involved in the degradation of plant polysaccharides, including cellulose, hemicellulose (xylan, xyloglucan, arabinoxylan and glucomannan) and pectin. Several glycosyl hydrolases (GH) families have been characterized and predicted in Aspergilli, along with carbohydrate esterases (CE) and polysaccharide lyases (PL) [3].

Different Aspergillus species (e.g., A. niger, A. fumigatus, A. tamarii, A. nidulans) showed the occurrence of genes coding for lignin-modifying enzymes [3,56], classified in the family of auxiliary activity enzymes (AA). These include multi-copper oxidases, such as laccases, ferroxidases and laccase-like multi-copper (AA1), heme peroxidases, such as lignin peroxidases, manganese peroxidases and versatile peroxidases (AA2) and, finally, 1,4-benzoquinone reductases (AA6).

Recently, lytic polysaccharide monooxygenases (LPMO) have also received special attention due to their boosting effect on hydrolytic enzymes' activity, suggesting a fundamental role of redox reactions in lignocellulose conversion. In the CAZy database, LPMOs belong to six AA families: AA9, AA10, AA11, AA13, AA14 and AA15, among which, the most widely studied are AA9 and AA10 [57].

In A. olivimuriae, the genome annotation of CAZymes allowed identifying a total of 148 protein-coding genes involved in lignocellulose degradation, belonging to 42 families. Among them, 109 genes were assigned to GH, 6 to $\mathrm{CE}, 3$ to PL and 30 to AA. CAZymes were further subdivided based on their substrate and the family they belong to, as suggested 
by Lombard et al. [58], and compared to Aspergillus species already characterized for their CAZyme content (Table 4) [3].

Table 4. Comparison of predicted number of glycosyl hydrolases $(\mathrm{GH})$, carbohydrate esterases (CE), polysaccharide lyases (PL) and of auxiliary activities (AA) found in the genome of A. olivimuriae (Aol) (this work), A. fumigatus (Af), A. nidulans (And), A. niger (Ang) and A. oryzae (Aor).

\begin{tabular}{|c|c|c|c|c|c|c|c|c|}
\hline \multirow{2}{*}{\multicolumn{2}{|c|}{ Substrate }} & \multirow{2}{*}{ Enzyme Activity } & \multirow{2}{*}{$\begin{array}{l}\text { CAZyme } \\
\text { Families }\end{array}$} & \multicolumn{5}{|c|}{ Number of Protein-Coding Predicted Genes } \\
\hline & & & & Aol + & $A f^{\mathrm{a}}$ & And ${ }^{\mathrm{a}}$ & Ang ${ }^{\text {a }}$ & Aor $^{\mathrm{a}}$ \\
\hline \multirow{5}{*}{\multicolumn{2}{|c|}{ Cellulose }} & $\beta$-1,4-Endoglucanase & $\begin{array}{c}\mathrm{GH} 3,-5,-6,-7,-9, \\
-12,-45\end{array}$ & $35(22)$ & 41 & 42 & 36 & 41 \\
\hline & & Cellobiohydrolase & GH7 & $3(3)$ & 4 & 3 & 2 & 3 \\
\hline & & $\beta-1,4-G l u c o s i d a s e$ & $\mathrm{GH} 1,-3$ & $17(11)$ & 23 & 23 & 22 & 26 \\
\hline & & Cellobiose dehydrogenase & $\mathrm{AA} 3, \mathrm{AA} 8$ & $2(2)$ & 2 & 2 & 2 & 2 \\
\hline & & $\begin{array}{l}\text { Lytic polysaccharide } \\
\text { monooxygenase }\end{array}$ & AA9 & $6(6)$ & 7 & 9 & 8 & 8 \\
\hline \multirow{19}{*}{ Hemicellulose } & \multirow{2}{*}{ Xylan } & $\beta$-1,4-Endoxylanase & GH10, $-11,-30$ & $6(5)$ & 8 & 5 & 6 & 8 \\
\hline & & $\beta-1,4-X y l o s i d a s e$ & $\mathrm{GH} 3,-43$ & $30(15)$ & 36 & 35 & 30 & 43 \\
\hline & \multirow{5}{*}{ Galactomannan } & $\beta$-1,4-Endomannanase & GH5 & $15(5)$ & 13 & 15 & 10 & 13 \\
\hline & & $\beta$-1,4-Mannosidase & $\mathrm{GH} 2$ & $6(2)$ & 6 & 10 & 6 & 7 \\
\hline & & $\beta-1,4-G a l a c t o s i d a s e$ & $\mathrm{GH} 2,-35$ & $9(3)$ & 11 & 14 & 11 & 14 \\
\hline & & $\alpha-1,4-G a l a c t o s i d a s e$ & GH27, -36 & $3(2)$ & 3 & 4 & 2 & 3 \\
\hline & & $\alpha$-Arabinofuranosidase & GH51, -54 & $3(3)$ & 3 & 3 & 5 & 4 \\
\hline & \multirow{6}{*}{ Xyloglucan } & $\beta$-1,4-endoglucanase & GH12, -74 & $3(3)$ & 6 & 3 & 4 & 4 \\
\hline & & $\alpha-, \beta$-Arabinofuranosidase & GH51, $-54,-127$ & $2(3)$ & 3 & 4 & 2 & 3 \\
\hline & & $\alpha-X y l o s i d a s e$ & GH31 & $10(1)$ & n.a. & $10^{\mathrm{b}}$ & $7^{b}$ & $10^{\mathrm{b}}$ \\
\hline & & $\alpha$-Fucosidase & GH29, -95 & $2(0)$ & n.a. & $3^{b}$ & $3^{b}$ & $3^{b}$ \\
\hline & & $\alpha-1,4-G a l a c t o s i d a s e$ & GH27, -36 & $3(2)$ & 3 & 4 & 2 & 3 \\
\hline & & $\beta-1,4-G a l a c t o s i d a s e$ & $\mathrm{GH} 2,-35$ & $9(3)$ & 11 & 14 & 11 & 14 \\
\hline & \multirow{6}{*}{ Arabinoxylan } & Arabinofuranohydrolase & GH62 & $2(2)$ & 2 & 2 & 1 & 2 \\
\hline & & $\alpha-, \beta$-Glucuronidase & GH67, -115, -154 & $4(2)$ & 2 & 2 & 1 & 5 \\
\hline & & $\alpha-1,4-G a l a c t o s i d a s e$ & $\mathrm{GH} 27,-36$ & $3(2)$ & 3 & 4 & 2 & 3 \\
\hline & & $\beta-1,4-G a l a c t o s i d a s e$ & $\mathrm{GH} 2,-35$ & $9(3)$ & 11 & 14 & 11 & 14 \\
\hline & & Acetyl xylan esterase & CE1, -5 & $3(4)$ & 10 & 7 & 8 & 10 \\
\hline & & Feruloyl esterase & CE1 & $1(1)$ & 5 & 3 & 3 & 5 \\
\hline \multirow{15}{*}{\multicolumn{2}{|c|}{ Pectin }} & Endo-polygalacturonases & GH28 & $3(1)$ & 14 & 9 & 22 & 21 \\
\hline & & $\alpha$-Rhamnosidase & GH78, 106 & $7(0)$ & 6 & 8 & 8 & 9 \\
\hline & & $\begin{array}{l}\alpha \text {-Arabinofuranosidase, } \\
\text { Arabinofuranohydrolase }\end{array}$ & GH51, -54, -62 & $4(5)$ & 5 & 5 & 6 & 6 \\
\hline & & Endoarabinanase & GH43 & $14(5)$ & 18 & 15 & 11 & 20 \\
\hline & & Exoarabinanase & GH93 & $3(2)$ & 3 & 2 & 1 & 3 \\
\hline & & $\beta-1,4$-Endogalactanase & GH53 & $1(1)$ & 1 & 1 & 1 & 1 \\
\hline & & $\begin{array}{l}\text { Unsaturated glucuronyl } \\
\text { hydrolase }\end{array}$ & GH88 & $1(0)$ & n.a. & $2^{b}$ & $1^{b}$ & $3^{b}$ \\
\hline & & $\begin{array}{l}\text { Unsaturated } \\
\text { rhamnogalacturonan hydrolase }\end{array}$ & GH105 & $2(0)$ & n.a. & $3^{b}$ & $2^{b}$ & $4^{b}$ \\
\hline & & $\beta-1,4-X y l o s i d a s e$ & $\mathrm{GH} 3,-43$ & $30(15)$ & 36 & 35 & 30 & 43 \\
\hline & & $\beta-1,4-G a l a c t o s i d a s e$ & $\mathrm{GH} 2,-35$ & $9(3)$ & 11 & 14 & 11 & 14 \\
\hline & & Pectate lyase & PL1 & $2(0)$ & 6 & 8 & 7 & 12 \\
\hline & & Rhamnogalacturonan lyase & PL4 & $1(0)$ & 3 & 4 & 2 & 4 \\
\hline & & Pectin methyl esterase PME & CE8 & $1(0)$ & 6 & 3 & 3 & 5 \\
\hline & & $\begin{array}{l}\text { Rhamnogalacturonan acetyl } \\
\text { esterase }\end{array}$ & CE12 & $2(0)$ & 3 & 2 & 2 & 4 \\
\hline & & Feruloyl esterase CE1 & CE1 & $1(3)$ & 5 & 3 & 3 & 5 \\
\hline \multirow{3}{*}{\multicolumn{2}{|c|}{ Lignin }} & $\begin{array}{l}\text { Laccase/p-diphenol:oxygen } \\
\text { oxidoreductase }\end{array}$ & AA1 & $3(2)$ & $1^{\mathrm{c}}$ & $2^{b}$ & $2^{c}$ & $4^{b}$ \\
\hline & & Lignin-modifying peroxidases & AA2 & $2(0)$ & $3^{c}$ & $0^{\mathrm{b}}$ & $2^{c}$ & $0^{\mathrm{b}}$ \\
\hline & & 1,4-benzoquinone reductase & AA6 & $1(1)$ & $0^{c}$ & $0^{b}$ & $2^{c}$ & $1^{b}$ \\
\hline
\end{tabular}

${ }^{a}$ Data from [55], integrated with ${ }^{\mathrm{b}}$ Cazy database (http: / / www.cazy.org/; accessed on 8 June 2021); ${ }^{\mathrm{c}}$ data from [3]. † For A. olivimuriae, the number of genes that have beeen manually annotated is shown between round brackets; The supplementary material titled "Annotations" contains the details related to the manual annotation.

A significant number of enzymes related to cellulose, hemicellulose and pectin degradation was identified [2,3]. In particular, the number of predicted genes for each family was close to that found in other Aspergillus species, except for acetyl xylan esterase and endo- 
polygalacturonases, which are significantly lower in number in A. olivimuriae (Table 4). The most frequently found glycoside hydrolases were endo $\beta$-1,4-glucanase (GH3,GH5, GH6,GH7, GH9, GH12, GH45) followed by $\beta$-xylosidase (GH3, GH43).

The number of genes related to lignin-modifying enzymes in $A$. olivimuriae was low and CAZy analysis identified 2, 1 and 3 genes coding for laccase, 1,4-benzoquinone reductase and lignin-modifying peroxidases, which, however, is in line with other Aspergillus species [3].

The presence of putative CAZyme-encoding genes in A. olivimuriae genome provides insight into its lignocelluloses-degrading enzyme potential, but cannot be directly related to its real degradation ability. In fact, in several works, it has been observed that the number of genes related to the degradation of a given polysaccharide is not necessarily correlated to the extents of its degradation, since fungal species rely on different strategies. For instance, Trichoderma reesei relies on the high production levels of a limited set of glycosyl hydrolases, while the white-rot basidiomycete Phanerochaete chrysosporium has a large repertoire of these enzymes [56]. For this reason, CAZy analysis is necessarily associated with functional approaches, such as enzymatic activity assays, and wet chemistry methods, to gain valuable insight into the actual behavior of the species of concern on specific lignocelluloses.

\subsection{Solid-State Production of A. olivimuriae Extracellular Glycosyl Hydrolases and Lyases}

As expected from the composition changes in the colonized materials and the CAZy prediction, we detected both glycosyl-hydrolase and lyase activities involved in the depolymerization of plant cell-wall polysaccharides in A. olivimuriae solid-state cultures. However, CAZyme production levels varied depending on the residue used and the presence or absence of the amendment.

Regarding cellulolytic enzymes, non-amended and amended cultures on RTB yielded the highest endo- $\beta$-1,4-glucanase activities (4.11 \pm 0.81 and $4.40 \pm 0.69 \mathrm{IU} \mathrm{g}^{-1}$ substrate, respectively) (Figure 1A). The presence of WB significantly increased this activity compared to homologous non-amended ones, but only in cultures on barley straw (4.40 \pm 0.58 vs. $3.20 \pm 0.59 \mathrm{IU} \mathrm{g}^{-1}$ substrate, respectively). Amended and non-amended cultures on RTB exhibited the highest cellobiohydrolase activity, and the presence of WB resulted in a significant increase in this activity, but only for SCG cultures $\left(2.51 \pm 0.42\right.$ vs. $1.51 \pm 0.28 \mathrm{IU} \mathrm{g}^{-1}$ substrate) (Figure 1B). As was already observed for endo- $\beta-1,4$-glucanase and cellobiohydrolase, among non-amended cultures, those on RTB gave the highest $\beta$-glucosidase activity and, in this case, the presence of WB led to a doubling of production levels $\left(2.68 \pm 0.38\right.$ vs. $1.33 \pm 0.15 \mathrm{IU} \mathrm{g}^{-1}$ substrate) (Figure $\left.1 \mathrm{C}\right)$. The total cellulolytic activity was also determined using Whatman filter paper $\mathrm{n}$. 1, a substrate with the merit of the inclusion of amorphous and para-crystalline regions, whose use was proposed by Ghose [28] and, later on, recommended by the IUPAC. For this reason, the activity of many commercial cellulolytic preparations is expressed in terms of Filter Paper Units [59]. Figure 1D shows that solid-state cultures on RTB and barley straw yielded the best activity values. The effect of WB was statistically significant in cultures carried out on RTB (2.27 \pm 0.40 vs. $1.48 \pm 0.34 \mathrm{FPU} \mathrm{g}^{-1}$ substrate), barley straw (1.95 \pm 0.26 vs. $2.98 \pm 0.60 \mathrm{FPU} \mathrm{g}^{-1}$ substrate) and in those on DSF (0.97 \pm 0.12 vs. $0.47 \pm 0.03$ FPU g $^{-1}$ substrate) (Figure 1D). Notably, CMCase, FPU and $\beta$-glucosidase production levels by Aspergillus coespitosus NRRL 1929 and $A$. tubingensis NRRL 4700 solid-state cultures on RTB were very similar to those observed with the strain under study on the same substrate [60]. DSF was poorly conducive to cellulase production in line with Mejias' results [51]; in that study, in the solid-state cultures of T. reseei ATCC 26921, a well-known cellulase-producing strain, the enzymatic activity never exceeded $1.1 \mathrm{FPU} \mathrm{g}^{-1}$ digestate. 


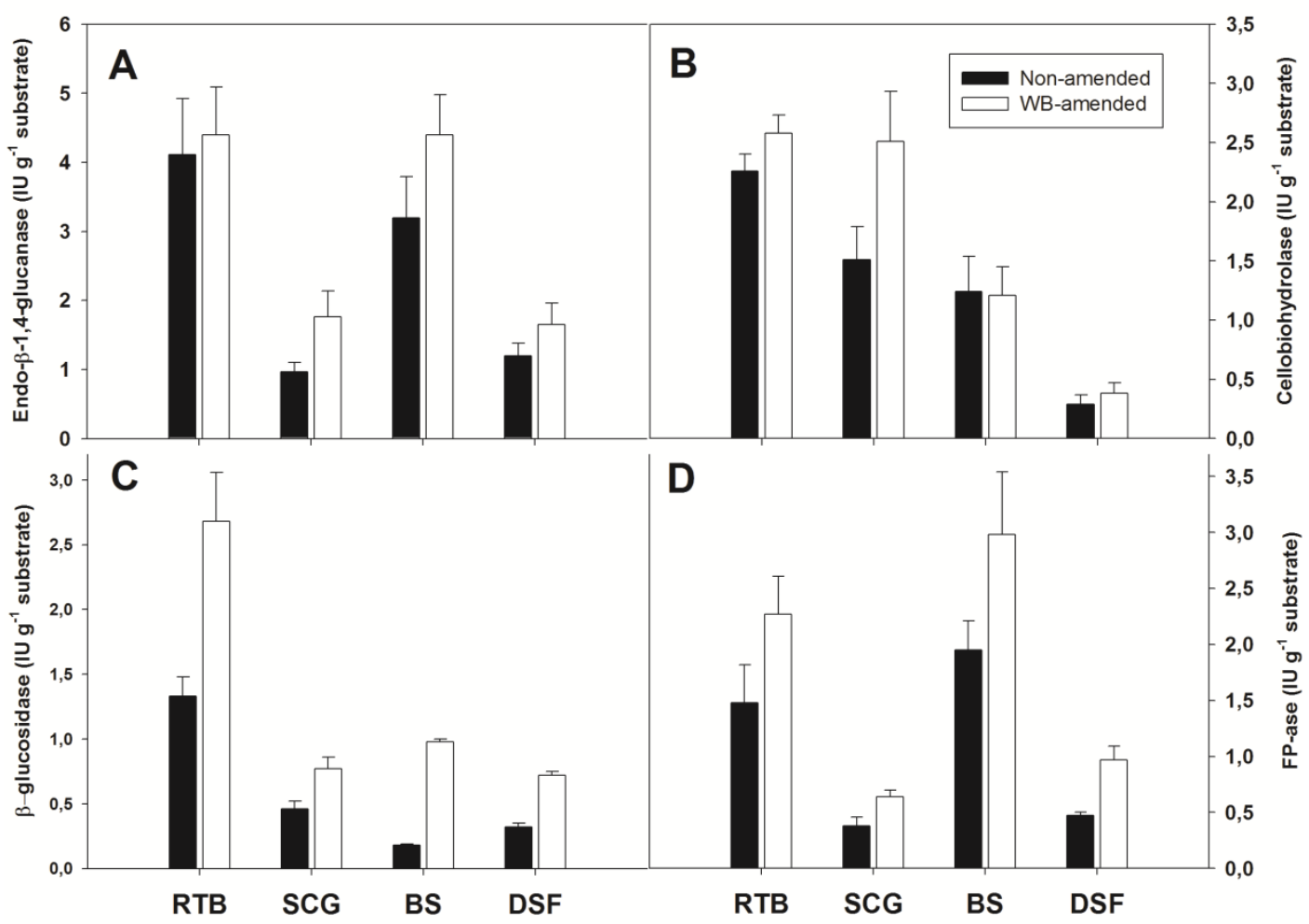

Figure 1. Specific activities, referred to unit mass of initial substrate, of endo- $\beta$-1,4-glucanase (A), cellobiohydrolase (B), $\beta$-glucosidase (C), and FP-ase (D) in 14-day-old solid-state cultures conducted on residual thistle biomass (RTB), spent coffee grounds (SCG), barley straw (BS) and digestate solid fraction (DSF) in the presence and in the absence of wheat bran $(\mathrm{WB})$ as the amendment. Data are the mean \pm standard deviation of four replicates.

However, Aspergillus olivimuriae 6C2 cellulase production levels do not compare with hyper-producing strains belonging to the same genus. To exemplify, Aspergillus terreus M11 solid-state cultures on different substrates, such as rape straw, wheat straw, wheat bran and corn stover, reached enzymatic CMCase and FPU activity levels ranging from 122 to $440 \mathrm{IU} \mathrm{g}^{-1}$ and 12 to $198 \mathrm{IU} \mathrm{g}^{-1}$, respectively [61]. CMCase, $\beta$-glucosidase and FPU activities in A. fumigatus ABK9 grown on WB-rice straw mixed substrate led to 824.21 and 254.44 and 106.2 $\mathrm{IU} \mathrm{g}^{-1}$, respectively [62].

Concerning hemicellulases, this study determined the activities of enzymes involved in the hydrolysis of two ubiquitous hemicellulose components, namely xylan and galactomannan. In addition to the endo- $\beta-1,4$-xylanase and galactomannase activities, which hydrolyze the $\beta(1 \rightarrow 4)$ glycosidic bonds between adjacent residues within the chain and in a random manner, we determined the activities of two exo-enzymes acting on these two polymers, namely $\beta$-xylosidase and $\beta$-mannosidase. The former catalyzes the xylobiose hydrolysis and the detachment of xylooligosaccharides from the xylan's nonreducing end. The latter brings about the detachment of mannosyl residues from the mannans' non-reducing end.

Among the non-amended cultures, those on barley straw attained the endo- $\beta-1,4$ xylanase activity (7.56 $\pm 0.79 \mathrm{IU} \mathrm{g}^{-1}$ substrate), but RTB cultures also led to significant activity levels (5.52 $\pm 1.17 \mathrm{IU} \mathrm{g}^{-1}$ substrate) (Figure 2A). Although the presence of WB increased the activity levels of this enzyme in cultures on barley straw and RTB (8.95 and $6.65 \mathrm{IU} \mathrm{g}^{-1}$ substrate, respectively), the only statistically significant increase occurred on SCG (3.23 \pm 0.76 vs. $1.04 \pm 0.18 \mathrm{IU} \mathrm{g}^{-1}$ substrate). It is likely that WB stimulated this enzyme's production, since this amendment brings xylose-based polymers to the growth substrate, whereas the hemicellulose fraction in SCG is devoid of these components $[36,39]$. On the same growth substrate, the presence of WB also led to a 4.5-fold increase in $\beta$-xylosidase activity (Figure 2B). As evidence of the previous considerations 
about the hemicellulose composition in SCG, the highest $\beta$-mannanase activity was found precisely on this matrix ( $3.72 \pm 0.2 \mathrm{IU} \mathrm{g}^{-1}$ substrate) (Figure $2 \mathrm{C}$ ), thus confirming the adequacy of coffee wastes to support the production of this enzyme by Aspergillus species [63]. The $\beta$-mannosidase activity was also the highest in cultures carried out on non-amended SCG $\left(0.90 \pm 0.04 \mathrm{IU} \mathrm{g}^{-1}\right.$ substrate) compared to other cultures (Figure 2D). Regardless of the growth substrate, the amendment's presence did not significantly affect the production of both $\beta$-mannanase and $\beta$-mannosidase (Figure $2 \mathrm{C}, \mathrm{D}$ ). As was already observed for cellulolytic enzymes, A. olivimuriae production levels of hemicellulases on the tested residues were significantly lower than those achieved by solid-state cultures of other Aspergillus species on different residues. For instance, de Oliveira Rodrigues et al. [64] found that $A$. niger SCBM1 and A. fumigatus SCBM6, grown individually on a mixture of spent bagasse and $W B$, produced very high activity levels for both endo- $\beta-1,4-x y l a n a s e$ (2271.7 and $1164.8 \mathrm{IU} \mathrm{g}^{-1}$ substrate, respectively) and $\beta$-xylosidase (145 and $2.5 \mathrm{IU} \mathrm{g}^{-1}$ substrate, respectively).

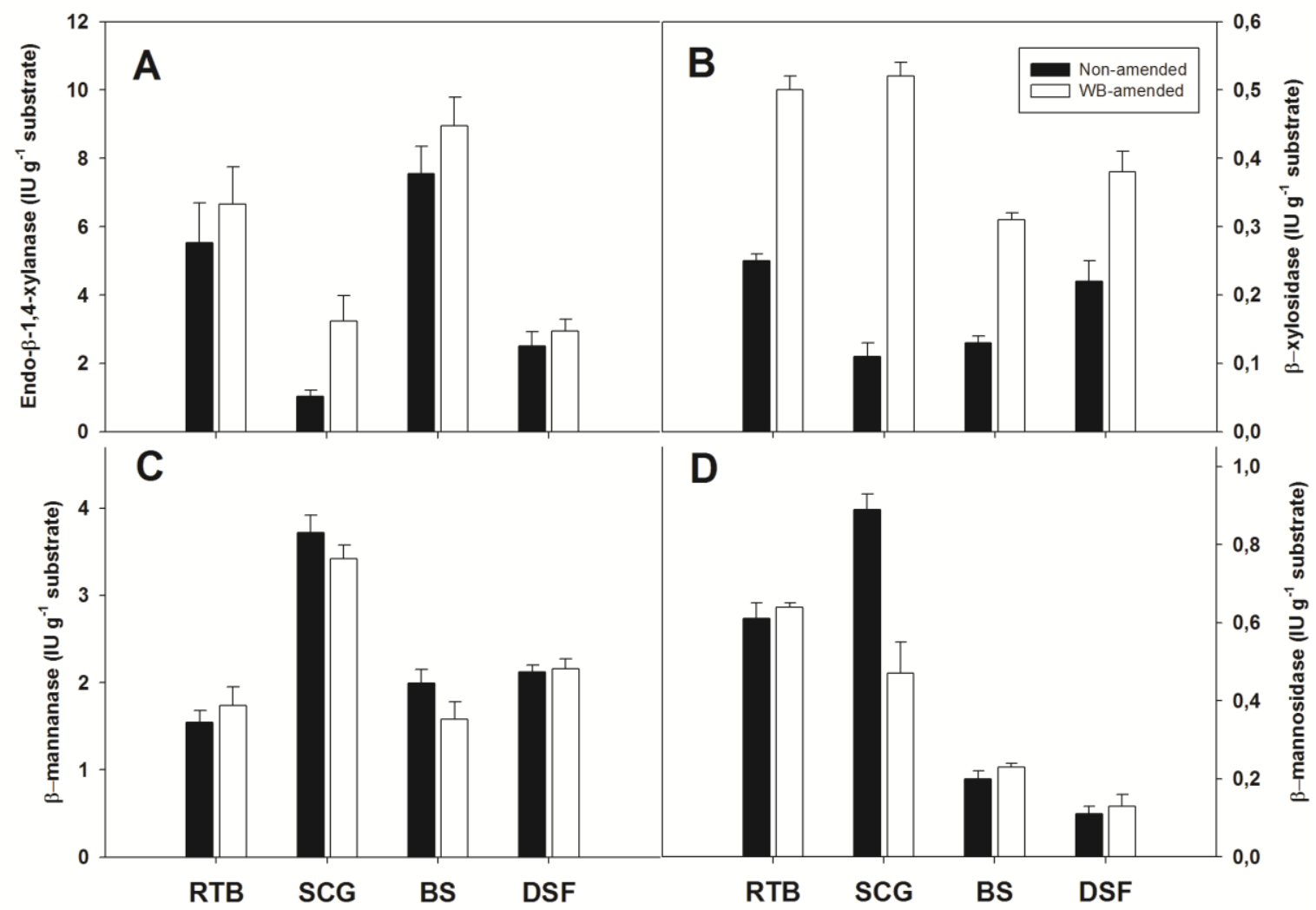

Figure 2. Specific activities, referred to unit mass of initial substrate, of endo- $\beta-1,4$-xylanase (A), $\beta$-xylosidase (B), $\beta$ mannanase (C), and $\beta$-mannosidase (D) in 14-day-old solid-state cultures conducted on residual thistle biomass (RTB), spent coffee grounds (SCG), barley straw (BS) and digestate solid fraction (DSF) in the presence and absence of wheat bran $(\mathrm{WB})$ as the amendment. Data are the mean \pm standard deviation of four replicates.

Although none of the used solid substrates is a pectin-rich material, the investigation was also extended to the determination of polymethylgalacturonase (E.C. 3.2.1.15), polygalacturonase (E.C. 3.2.1.67) and pectinesterase (E.C. 3.1.1.11) activities. Polymethylgalacturonase, ambiguously called pectinase, catalyzes the random hydrolysis of $\alpha(1 \rightarrow 4)$ bonds between adjacent residues in pectate and other galacturonans and, depending on the microbial source, has different tolerances to the methyl esterification of galacturonic residues. On the contrary, polygalacturonase is specific to D-homogalacturonan oligomers and cannot degrade unsaturated or methyl esterified substrates. The role of pectinesterase is to facilitate the action of depolymerizing enzymes by hydrolyzing the carboxylic esters present in the D-galacturonic residues of the pectin, producing pectates and methanol. 
In addition to these hydrolases' activities, the activities of pectin lyase (EC 4.2.2.10) and pectate lyase (E.C. 4.2.2.2) were also measured. These enzymes break the $\alpha(1 \rightarrow 4)$ bond between D-galacturonic residues adjacent through a $\beta$-elimination mechanism that leads to the production at the non-reducing end of one of the two fragments of an unsaturated residue between C4 and C5 (4-deoxy-alpha-D-galact-4-en-uronosyl groups).

Table 5 shows that, among the non-amended substrates, the best polymethylgalacturonase, polygalacturonase and pectinesterase activities were found in cultures carried out on RTB $\left(2.30 \pm 0.18,1.27 \pm 0.21\right.$ and $1.24 \pm 0.20 \mathrm{IU} \mathrm{g}^{-1}$ substrate, respectively). Significantly increased polymethylgalacturonase activities, due to the presence of WB compared to the non-amended counterpart, were found on RTB $\left(2.99 \pm 0.27\right.$ vs. $2.30 \pm 0.18 \mathrm{IU} \mathrm{g}^{-1}$ substrate) and barley straw (1.49 \pm 0.10 vs. $0.99 \pm 0.13 \mathrm{IU} \mathrm{g}^{-1}$ substrate). In the case of polygalacturonase, the only cultures to benefit from the presence of WB were those carried out RTB $\left(1.93 \pm 0.09\right.$ vs. $1.27 \pm 0.21 \mathrm{IU} \mathrm{g}^{-1}$ substrate $)$ and pectinesterase activities $\left(2.16 \pm 0.33\right.$ vs. $1.24 \pm 0.20 \mathrm{IU} \mathrm{g}^{-1}$ substrate). Although detected in all the solid-state cultures, the lyase activities were significantly lower than those of hydrolases (Table 5).

Table 5. Specific activities, referred to unit mass of the solid substrate, of polymethylgalacturonase (PMG), pectin esterase (PE), polygalacturonase (PG), pectin lyase, and pectase lyase in A. olivimuriae solid-state cultures conducted for 14 days at $301.15 \mathrm{~K}$ on residual thistle biomass (RTB), spent coffee rounds (SCG), barley straw (BS) e digestate solid fraction (DSF) in the absence and presence of wheat bran (WB). Data are the means \pm standard deviation of 4 replicates. Multiple pair-wise comparisons were made with Tukey's test, and identical letters denote that column means were not statistically different $(p>0.05)$.

\begin{tabular}{|c|c|c|c|c|c|}
\hline Culture & $\begin{array}{c}\text { PMG } \\
\text { (IU g } \text { g }^{-1} \text { Substrate) }\end{array}$ & $\begin{array}{c}\text { PE } \\
\text { (IU } \mathrm{g}^{-1} \text { Substrate) }\end{array}$ & $\begin{array}{c}\text { PG } \\
\text { (IU g } \mathrm{g}^{-1} \text { Substrate) }\end{array}$ & $\begin{array}{c}\text { Pectin Lyase } \\
\text { (IU } \mathrm{g}^{-1} \text { Substrate) }\end{array}$ & $\begin{array}{c}\text { Pectate Lyase } \\
\text { (IU } \mathrm{g}^{-1} \text { Substrate) }\end{array}$ \\
\hline RTB & $2.30 \pm 0.18 c$ & $1.24 \pm 0.20 c$ & $1.27 \pm 0.21 \mathrm{c}$ & $0.33 \pm 0.08 \mathrm{bc}$ & $0.11 \pm 0.03 \mathrm{a}$ \\
\hline RTB + WB & $2.99 \pm 0.27 \mathrm{~d}$ & $2.16 \pm 0.33 \mathrm{~d}$ & $1.93 \pm 0.09 \mathrm{~d}$ & $0.31 \pm 0.01 \mathrm{~b}$ & $0.08 \pm 0.01 \mathrm{a}$ \\
\hline SCG & $0.66 \pm 0.05 a$ & $0.39 \pm 0.03 \mathrm{ab}$ & $0.54 \pm 0.06 \mathrm{a}$ & $0.17 \pm 0.05 a$ & $0.12 \pm 0.06 \mathrm{ab}$ \\
\hline $\mathrm{SCG}+\mathrm{WB}$ & $0.73 \pm 0.08 \mathrm{a}$ & $0.53 \pm 0.08 b$ & $0.56 \pm 0.11 \mathrm{a}$ & $0.15 \pm 0.01 \mathrm{a}$ & $0.10 \pm 0.02 \mathrm{a}$ \\
\hline BS & $0.99 \pm 0.13 \mathrm{a}$ & $0.10 \pm 0.01 \mathrm{a}$ & $0.74 \pm 0.11 \mathrm{ab}$ & $0.19 \pm 0.04 \mathrm{a}$ & $0.20 \pm 0.04 \mathrm{ab}$ \\
\hline $\mathrm{BS}+\mathrm{WB}$ & $1.49 \pm 0.13 b$ & $0.06 \pm 0.02 \mathrm{a}$ & $0.91 \pm 0.11 b$ & $0.31 \pm 0.02 b$ & $0.25 \pm 0.04 b$ \\
\hline DSF & $0.49 \pm 0.12 \mathrm{a}$ & $0.14 \pm 0.05 \mathrm{ab}$ & $0.52 \pm 0.07 \mathrm{a}$ & $0.19 \pm 0.04 \mathrm{a}$ & $0.22 \pm 0.02 \mathrm{~b}$ \\
\hline $\mathrm{DSF}+\mathrm{WB}$ & $0.71 \pm 0.09 \mathrm{a}$ & $0.09 \pm 0.02 \mathrm{a}$ & $0.73 \pm 0.11 \mathrm{a}$ & $0.46 \pm 0.05 c$ & $0.26 \pm 0.04 b$ \\
\hline
\end{tabular}

\subsection{Solid-State Production of Lignin-Modifying Enzymes by A. olivimuriae}

A further purpose of this work was to verify the presence of ligninolytic enzymes in A. olivimuriae $6 \mathrm{C} 2$ solid-state cultures and determine their activity. This strain, mistakenly identified in a previous study as A. fumigatus $6 \mathrm{C} 2$, based on ITS sequences and morphological characters, underwent a battery of agar plate tests that indicated the presence of lignin-modifying enzymes (formation of a brown halo in the Bavendamm's test with tannic acid, decolorization of Poly-R478, formation of ABTS oxidation halos using the underlay agar technique) [65]. In the same study, the strain produced detectable laccase and peroxidase activities in the same work, albeit at low levels. Following the correct identification of this species and sequencing of its genome, this study assessed the presence of putative genes coding for ligninolytic enzymes.

Therefore, it was reasonable to expect these enzymes' presence under a cultural condition, such as solid-state fermentation on lignocellulose-based substrates, which reproduces those encountered in natural habitats. As shown in Table 6, activity levels were very low and in line with those found in the previously mentioned work [65]. Among the non-amended cultures, the best laccase and peroxidase production levels were found in RTB and SCG; in these growth substrates, the presence of WB led to significantly increased laccase and peroxidase activities. However, on the tested substrates, the production levels of these enzymes were markedly lower than those observed in solid-state cultures of other Aspergillus species, such as A. fumigatus SCBM6 and A. niger SCBM1 and ATCC 1004 conducted on different residues $[64,66]$. For instance, solid-state cultures of $A$. niger ATCC 
1004, grown on palm cactus husk, yielded laccase activity, which was around 173-fold higher than the best production achieved with A. olivimuriae [66].

Table 6. Specific activities, referred to unit mass of the solid substrate and extracellular protein, of laccase and peroxidase in A. olivimuriae solid-state cultures conducted for 14 days at $301.15 \mathrm{~K}$ on residual thistle biomass (RTB), spent coffee rounds (SCG), barley straw (BS) e digestate solid fraction (DSF) in the absence and in the presence of wheat bran (WB). Data are the means \pm standard deviation of 4 replicates. Multiple pair-wise comparisons were made with Tukey's test, and identical letters denote that column means were not statistically different $(p>0.05)$.

\begin{tabular}{|c|c|c|c|c|}
\hline \multirow[b]{2}{*}{ Culture } & \multicolumn{2}{|c|}{ Laccase } & \multicolumn{2}{|c|}{ Peroxidase } \\
\hline & $\begin{array}{c}\left(\mathrm{IU} \mathrm{g}^{-1}\right. \\
\text { Substrate) } \\
\left(\times 10^{-3}\right)\end{array}$ & $\begin{array}{c}{\text { (IU } \mathrm{mg}^{-1}} \\
\text { Protein) } \\
\left(\times 10^{-3}\right)\end{array}$ & $\begin{array}{c}\left(\mathrm{IU} \mathrm{g} \mathrm{g}^{-1}\right. \\
\text { Substrate }) \\
\left(\times 10^{-3}\right)\end{array}$ & $\begin{array}{c}{\text { (IU } \mathrm{mg}^{-1}} \\
\text { Protein) } \\
\left(\times 10^{-3}\right)\end{array}$ \\
\hline RTB & $32.8 \pm 0.4 c$ & $11.3 \pm 0.1$ & $30.0 \pm 1.6 \mathrm{~b}$ & $10.4 \pm 1.3$ \\
\hline $\mathrm{RTB}+\mathrm{WB}$ & $49.2 \pm 3.2 \mathrm{~d}$ & $14.1 \pm 2.5$ & $47.4 \pm 6.9 c$ & $13.6 \pm 1.0$ \\
\hline SCG & $32.9 \pm 4.1 c$ & $16.5 \pm 0.4$ & $23.6 \pm 3.3 b$ & $11.8 \pm 0,6$ \\
\hline $\mathrm{SCG}+\mathrm{WB}$ & $41.3 \pm 3.0 \mathrm{~d}$ & $21.9 \pm 1.9$ & $27.6 \pm 3.8 b$ & $14.6 \pm 1.8$ \\
\hline BS & $20.0 \pm 1.6 \mathrm{~b}$ & $3.6 \pm 0.1$ & $13.8 \pm 2.5 \mathrm{a}$ & $2.5 \pm 0.8$ \\
\hline $\mathrm{BS}+\mathrm{WB}$ & $18.6 \pm 1.1 b$ & $3.7 \pm 0.2$ & $15.6 \pm 3.2 \mathrm{ab}$ & $3.1 \pm 1.0$ \\
\hline DSF & $2.7 \pm 0.6 \mathrm{a}$ & $0.7 \pm 0.1$ & n. d. $\ddagger$ & n. d. $\ddagger$ \\
\hline $\mathrm{DSF}+\mathrm{WB}$ & $3.6 \pm 0.8 \mathrm{a}$ & $1.0 \pm 0.2$ & n. d. $\ddagger$ & n. d. $\ddagger$ \\
\hline
\end{tabular}

$\ddagger$ n.d., not detected.

\section{Conclusions}

The integrated use of different procedures made it possible to acquire information regarding the lignocellulolytic attitudes of Aspergillus olivimuriae, a recently described species. The choice of using production waste derived from four different supply chains increased the applicative value of this study. For new taxa, providing information of an applicative nature can be helpful to those who want to undertake screening procedures to evaluate changes to specific materials or productions. Among the tested substrates, RTB was the most conducive to endo- $\beta$-1,4-glucanase and cellobiohydrolase productions, due to its high cellulose content, while $\beta$-mannanase production was highest in SCG, the hemicellulose of which are mainly composed of glucomannans and galactomannans. In general, the hemicellulolytic attitude of A. olivimuriae prevailed over the cellulolytic one, and this behavior was particularly evident in the DSF, where hemicellulose degradation was equal to $60 \%$. Irrespective of the waste used, and as opposed to other Aspergillus species, the strain under study did not show ligninolytic potential.

Supplementary Materials: The following Supplementary Materials are available online at https:/ / www.mdpi.com/article/10.3390/app11125349/s1: Excel file, S1_dbCAN2_output_file_A_olivimuriae.xls; Excel file, S2_Annotations.xls.

Author Contributions: Conceptualization, S.C. and A.D.; Formal analysis, E.C. and S.C.; Funding acquisition, M.P.; Investigation, E.C., S.C., C.R. and A.D.; Methodology, E.C.; Supervision, A.D.; Writing-original draft, A.D.; Writing-review \& editing, S.C. and M.P. All authors have read and agreed to the published version of the manuscript.

Funding: This research received no external funding.

Data Availability Statement: Data is contained within the article or Supplementary Materials.

Acknowledgments: This work was partially supported by the "Departments of Excellence-2018" Program (Dipartimenti di Eccellenza) of the Italian Ministry of Education, University and Research (MIUR), DIBAF-Department of University of Tuscia, Project “Landscape 4.0—food, wellbeing, and environment".

Conflicts of Interest: The authors declare no conflict of interest. 


\section{Symbols and Abbreviations}

BS, barley straw; CAZy, Carbohydrate-Active EnZyme database; DSF, digestate solid fraction; IC, incubation controls; IU, International Units; $\mathrm{MBTH}$, 3-methyl-2-benzothiazolinone hydrazone; MEA, malt extract agar; $\mathrm{OM}$, organic matter; $\mathrm{PG}$, polygalacturonase; $\mathrm{PMG}$, polymethylgalacturonase; $\mathrm{SCG}$, spent coffee grounds; $\mathrm{WB}$, wheat bran; $w_{H C}$, mass fraction of holocellulose; $w_{M}$, mass fraction of moisture in solid-state cultures; $w_{W B}$, mass fraction of wheat bran in amended cultures; SSC, solidstate cultures; $\mathrm{Y}_{\mathrm{GLC} / \mathrm{S}}$, biomass yield per unit mass of $\mathrm{OM}$ consumed.

\section{References}

1. Troiano, D.; Orsat, V.; Dumont, M.J. Status of filamentous fungi in integrated biorefineries. Renew. Sustain. Energy Rev. 2020, 117, 109472. [CrossRef]

2. Culleton, H.; McKie, V.; de Vries, R.P. Physiological and molecular aspects of degradation of plant polysaccharides by fungi: What have we learned from Aspergillus? Biotechnol. J. 2013, 8, 884-894. [CrossRef]

3. Ma, Y.; Ling, T.J.; Su, X.Q.; Jiang, B.; Nian, B.; Chen, L.J.; Liu, L.M.; Zhang, Z.Y.; Wang, D.P.; Mu, Y.Y.; et al. Integrated proteomics and metabolomics analysis of tea leaves fermented by Aspergillus niger, Aspergillus tamarii and Aspergillus fumigatus. Food Chem. 2021, 334, 127560. [CrossRef] [PubMed]

4. Cantarel, B.L.; Coutinho, P.M.; Rancurel, C.; Bernard, T.; Lombard, V.; Henrissat, B. The Carbohydrate-Active EnZymes database (CAZy): An expert resource for glycogenomics. Nucleic Acids Res. 2009, 37, 5. [CrossRef] [PubMed]

5. Coutinho, P.M.; Andersen, M.R.; Kolenova, K.; Benoit, I.; Gruben, B.S.; Trejo-Aguilar, B.; Visser, H.; van Solingen, P.; Pakula, T.; Seiboth, B.; et al. Post-genomic insights into the plant polysaccharide degradation potential of Aspergillus nidulans and comparison to Aspergillus niger and Aspergillus oryzae. Fung. Genet. Biol. 2009, 46, S161-S169. [CrossRef]

6. Levasseur, A.; Drula, E.; Lombard, V.; Coutinho, P.M.; Henrissat, B. Expansion of the enzymatic repertoire of the CAZy database to integrate auxiliary redox enzymes. Biotechnol. Biofuels 2013, 6, 1-14. [CrossRef]

7. Kanayama, N.; Tohru, S.; Keiichi, K. Purification and characterization of an alkaline manganese peroxidase from Aspergillus terreus LD-1. J. Biosci. Bioeng. 2002, 93, 405-410. [CrossRef]

8. Fan, Y.; Zhang, Z.; Wang, F.; Li, J.; Hu, K.; Du, Z. Lignin degradation in corn stover catalyzed by lignin peroxidase from Aspergillus oryzae broth: Effects of conditions on the kinetics. Renew. Energy 2019, 130, 32-40. [CrossRef]

9. Jurjevic, Z.; Peterson, S.W.; Horn, B.W. Aspergillus section Versicolores: Nine new species and multilocus DNA sequence-based phylogeny. IMA Fung. 2012, 3, 59-79. [CrossRef]

10. Hubka, V.; Novàkovà, A.; Kolàrík, M.; Jurjevic, Ž.; Peterson, S.W. Revision of Aspergillus section Flavipedes: Seven new species and proposal of section Jani sect. nov. Mycologia 2015, 107, 169-208. [CrossRef]

11. Arzanlou, M.; Samadi, R.; Frisvad, J.C.; Houbraken, J.; Ghosta, Y. Two novel Aspergillus species from hypersaline soils of the national park of lake Urmia, Iran. Mycol. Prog. 2016, 15, 1081-1092. [CrossRef]

12. Martinelli, L.; Zalar, P.; Gunde-Cimerman, N.; Azua-Bustos, A.; Sterflinger, K.; Pinar, G. Aspergillus atacamensis and A. salisburgensis: Two new halophilic species from hypersaline/arid habitats with a phialosimplex-like morphology. Extremophiles 2017, 21, 755-773. [CrossRef]

13. Crognale, S.; Pesciaroli, L.; Felli, M.; Petruccioli, M.; D'Annibale, A.; Bresciani, A.; Peterson, S.W. Aspergillus olivimuriae sp. nov., a halotolerant species isolated from olive brine. Int. J. Syst. Evolut. Microbiol. 2019, 69, 2899-2906. [CrossRef]

14. Singhania, R.R.; Patel, A.K.; Soccol, C.R.; Pandey, A. Recent advances in solid-state fermentation. Biochem. Eng. J. 2009, 44, $13-18$. [CrossRef]

15. El-Bakry, M.; Abraham, J.; Cerda, A.; Barrena, R.; Ponsá, S.; Gea, T.; Sánchez, A. From wastes to high value added products: Novel aspects of SSF in the production of enzymes. Crit. Rev. Environ. Sci. Technol. 2015, 45, 1999-2042. [CrossRef]

16. Zhang, H.; Yohe, T.; Huang, L.; Entwistle, S.; Wu, P.; Yang, Z.; Busk, P.K.; Xu, Y.; Yin, Y. dbCAN2: A meta server for automated carbohydrate-active enzyme annotation. Nucleic Acids Res. 2018, 46, W95-W101. [CrossRef]

17. Segato, F.; Damásio, A.R.; de Lucas, R.C.; Squina, F.M.; Prade, R.A. Genomics review of holocellulose deconstruction by aspergilli. Microbiol. Mol. Biol. Rev. 2014, 78, 588-613. [CrossRef]

18. Cruz, R.; Cardoso, M.M.; Fernandes, L.; Oliveira, M.; Mendes, E.; Baptista, P.; Morais, S.; Casal, S. Espresso coffee residues: A valuable source of unextracted compounds. J. Agric. Food Chem. 2012, 60, 7777-7784. [CrossRef]

19. Van Soest, P.J.; Robertson, J.B.; Lewis, B.A. Methods for dietary fiber, neutral detergent fiber, and nonstarch polysaccharides in relation to animal nutrition. J. Dairy Sci. 1991, 74, 3583-3597. [CrossRef]

20. Brozzoli, V.; Bartocci, S.; Terramoccia, S.; Contò, G.; Federici, F.; D’Annibale, A.; Petruccioli, M. Stoned olive pomace fermentation with Pleurotus species and its evaluation as a possible animal feed. Enzyme Microb. Technol. 2010, 46, 223-228. [CrossRef]

21. Ainsworth, E.; Gillespie, K. Estimation of total phenolic content and other oxidation substrates in plant tissues using FolinCiocalteu reagent. Nat. Protoc. 2007, 2, 875-877. [CrossRef] [PubMed]

22. Miller, G.L. Use of dinitrosalicylic acid reagent for determination of reducing sugar. Anal. Chem. 1959, 31, 426-428. [CrossRef]

23. Paredes, C.; Roig, A.; Bernal, M.P.; Sanchez-Monedero, M.A.; Cegarra, J. Evolution of organic matter and nitrogen during co-composting of olive mill wastewater with solid organic wastes. Biol. Fertil. Soils 2000, 32, 222-227. [CrossRef] 
24. Scotti, C.T.; Vergoignan, C.; Feron, G.; Durand, A. Glucosamine measurement as indirect method for biomass estimation of Cunninghamella elegans grown in solid state cultivation conditions. Biochem. Eng. J. 2001, 7, 1-5. [CrossRef]

25. Sakurai, Y.; Lee, T.H.; Shiota, H. On the convenient method for glucosamine estimation in koji. Agric. Biol. Chem. 1977, 41, 619-624.

26. Bradford, M.M. A rapid and sensitive method for the quantitation of microgram quantities of protein utilizing the principle of protein-dye binding. Anal. Biochem. 1976, 72, 248-254. [CrossRef]

27. Giovannozzi-Sermanni, G.; D’Annibale, A.; Perani, C.; Porri, A.; Pastina, F.; Minelli, V.; Vitale, N.; Gelsomino, A. Characteristics of paper handsheets after combined biological pretreatments and conventional pulping of wheat straw. Tappi J. 1994, 77, 151-158.

28. Ghose, T.K. Measurement of cellulase activities. Pure Appl. Chem. 1987, 59, 257-268. [CrossRef]

29. Wood, T.M.; Bhat, K.M. Methods for measuring cellulase activities. Methods Enzymol. 1988, 160, 87-112.

30. Meijer, M.; Houbraken, J.A.M.P.; Dalhuijsen, S.; Samson, R.A.; De Vries, R.P. Growth and hydrolase profiles can be used as characteristics to distinguish Aspergillus niger and other black aspergilli. Stud. Mycol. 2011, 69, 19-30. [CrossRef]

31. Heerd, D.; Yegin, S.; Tari, C.L.; Fernandez-Lahore, M. Pectinase enzyme-complex production by Aspergillus spp. in solid-state fermentation: A comparative study. Food Bioprod. Process. 2012, 90, 102-110. [CrossRef]

32. Vilariño, C.; Del Giorgio, J.F.; Hours, R.A.; Cascone, O. Spectrophotometric method for fungal pectinesterase activity determination. LWT-Food Sci. Technol. 1993, 26, 107-110. [CrossRef]

33. del Pilar Castillo, M.; Ander, P.; Stenstrom, J. Lignin and manganese peroxidase activity in extracts from straw solid substrate fermentations. Biotechnol Techn. 1997, 11, 701-706. [CrossRef]

34. Balandrán-Quintana, R.R.; Mercado-Ruiz, J.N.; Mendoza-Wilson, A.M. Wheat bran proteins: A review of their uses and potential. Food Rev. Int. 2015, 31, 279-293. [CrossRef]

35. Bartłomiej, S.; Justyna, R.K.; Ewa, N. Bioactive compounds in cereal grains-occurrence, structure, technological significance and nutritional benefits-A review. Food Sci. Technol. Int. 2012, 18, 559-568. [CrossRef]

36. Mussatto, S.I.; Carneiro, L.M.; Silva, J.P.; Roberto, I.C.; Teixeira, J. A study on chemical constituents and sugars extraction from spent coffee grounds. Carbohydr. Polym. 2011, 83, 368-374. [CrossRef]

37. Kwon, E.E.; Yi, H.; Jeon, Y.J. Sequential co-production of biodiesel and bioethanol with spent coffee grounds. Bioresour. Technol. 2013, 136, 475-480. [CrossRef] [PubMed]

38. Couto, R.M.; Fernandes, J.; Da Silva, M.G.; Simoes, P.C. Supercritical fluid extraction of lipids from spent coffee grounds. J. Supercrit. Fluids 2009, 51, 159-166. [CrossRef]

39. Burniol-Figols, A.; Cenian, K.; Skiadas, I.V.; Gavala, H.N. Integration of chlorogenic acid recovery and bioethanol production from spent coffee grounds. Biochem. Eng. J. 2016, 116, 54-64. [CrossRef]

40. Panusa, A.; Zuorro, A.; Lavecchia, R.; Marrosu, G.; Petrucci, R.; Farmaco, D. Recovery of natural antioxidants from spent coffee grounds. J. Agric. Food Chem. 2013, 61, 4162-4168. [CrossRef]

41. Stuper-Szablewska, K.; Perkowski, J. Phenolic acids in cereal grain: Occurrence, biosynthesis, metabolism and role in living organisms. Crit. Rev. Food Sci. Nutr. 2019, 59, 664-675. [CrossRef]

42. Ferri, M.; Happel, A.; Zanaroli, G.; Bertolini, M.; Chiesa, S.; Commisso, M.; Guzzo, F.; Tassoni, A. Advances in combined enzymatic extraction of ferulic acid from wheat bran. New Biotechnol. 2020, 56, 38-45. [CrossRef] [PubMed]

43. Krawczyk, H.; Arkell, A.; Jönsson, A.S. Impact of prefiltration on membrane performance during isolation of hemicelluloses extracted from wheat bran. Separ. Purif. Technol. 2013, 116, 192-198. [CrossRef]

44. Merali, Z.; Collins, S.R.; Elliston, A.; Wilson, D.R.; Käsper, A.; Waldron, K.W. Characterization of cell wall components of wheat bran following hydrothermal pretreatment and fractionation. Biotechnol. Biofuels 2015, 8, 23. [CrossRef] [PubMed]

45. Prinsen, P.; Gutiérrez, A.; Faulds, C.B.; Del Río, J.C. Comprehensive study of valuable lipophilic phytochemicals in wheat bran. J. Agric. Food Chem. 2014, 62, 1664-1673. [CrossRef]

46. Musaalbakri, A.M.; Webb, C. Estimation of growth in solid state fermentation: A review. Malays. J. Microbiol. $2018,14,61-69$.

47. Sharma, P.D.; Fisher, P.J.; Webster, J. Critique of the chitin assay technique for the estimation of fungal biomass. Transact. British Mycol. Soc. 1977, 69, 479-483. [CrossRef]

48. Andersen, M.R.; Lehmann, L.; Nielsen, J. Systemic analysis of the response of Aspergillus niger to ambient pH. Genome Biol. 2009, 10, 1-14. [CrossRef]

49. Mai, H.T.N.; Lee, K.M.; Choi, S.S. Enhanced oxalic acid production from corncob by a methanol-resistant strain of Aspergillus niger using semi solid-sate fermentation. Process Biochem. 2016, 51, 9-15. [CrossRef]

50. Poulsen, L.; Andersen, M.R.; Lantz, A.E.; Thykaer, J. Identification of a transcription factor controlling pH-dependent organic acid response in Aspergillus niger. PLoS ONE 2012, 7, e50596. [CrossRef]

51. Mejias, L.; Cerda, A.; Barrena, R.; Gea, T.; Sánchez, A. Microbial strategies for cellulase and xylanase production through solid-state fermentation of digestate from biowaste. Sustainability 2018, 10, 2433. [CrossRef]

52. Hatakka, A.; Hammel, K.E. Fungal biodegradation of lignocelluloses. In Industrial Applications; Esser, K., Hofrichter, M., Eds.; Springer: Berlin, Germany, 2011; pp. 319-340.

53. Cardoso Duarte, J.; Costa-Ferreira, M. Aspergilli and lignocellulosics: Enzymology and biotechnological applications. FEMS Microbiol. Rev. 1994, 13, 377-386. [CrossRef] 
54. Santos, J.I.; Fillat, Ú.; Martín-Sampedro, R.; Ballesteros, I.; Manzanares, P.; Ballesteros, M.; Eugenio, M.E.; Ibarra, D. Ligninenriched fermentation residues from bioethanol production of fast-growing poplar and forage sorghum. Bioresources 2015, 10, 5215-5232. [CrossRef]

55. Hasanin, M.S.; Darwesh, O.M.; Matter, I.A.; El-Saied, H. Isolation and characterization of non-cellulolytic Aspergillus flavus EGYPTA5 exhibiting selective ligninolytic potential. Biocatal. Agric. Biotechnol. 2019, 17, 160-167. [CrossRef]

56. Rytioja, J.; Hildén, K.; Yuzon, J.; Hatakka, A.; de Vries, R.P.; Mäkelä, M.R. Plant-polysaccharide-degrading enzymes from basidiomycetes. Microbiol. Mol. Biol. Rev. 2014, 78, 614-649. [CrossRef]

57. Eijsink, V.G.; Petrovic, D.; Forsberg, Z.; Mekasha, S.; Røhr, Å.K.; Várnai, A.; Bissaro, B.; Vaaje-Kolstad, G. On the functional characterization of lytic polysaccharide monooxygenases (LPMOs). Biotechnol. Biofuels 2019, 12, 1-16. [CrossRef]

58. Lombard, V.; Golaconda Ramulu, H.; Drula, E.; Coutinho, P.M.; Henrissat, B. The carbohydrate-active enzymes database (CAZy) in 2013. Nucleic Acids Res. 2014, 42, D490-D495. [CrossRef]

59. Eveleigh, D.E.; Mandels, M.; Andreotti, R.; Roche, C. Measurement of saccharifying cellulase. Biotechnol. Biofuels 2009, 6, 1-8. [CrossRef]

60. Crognale, S.; Liuzzi, F.; D'Annibale, A.; de Bari, I.; Petruccioli, M. Cynara cardunculus a novel substrate for solid-state production of Aspergillus tubingensis cellulases and sugar hydrolysates. Biomass Bioenerhy 2019, 127, 105276. [CrossRef]

61. Gao, J.; Weng, H.; Zhu, D.; Yuan, M.; Guan, F.; Xi, Y. Production and characterization of cellulolytic enzymes from the thermoacidophilic fungal Aspergillus terreus M11 under solid-state cultivation of corn stover. Biores. Technol. 2008, 99, 7623-7629. [CrossRef] [PubMed]

62. Das, A.; Paul, T.; Halder, S.K.; Jana, A.; Maity, C.; Mohapatra, P.K.D.; Pati, B.R.; Mondal, K.C. Production of cellulolytic enzymes by Aspergillus fumigatus ABK9 in wheat bran-rice straw mixed substrate and use of cocktail enzymes for deinking of waste office paper pulp. Biores. Technol. 2013, 128, 290-296. [CrossRef] [PubMed]

63. Favaro, C.P.; Baraldi, I.J.; Casciatori, F.P.; Farinas, C.S. $\beta$-Mannanase production using coffee industry waste for application in soluble coffee processing. Biomolecules 2020, 10, 227. [CrossRef] [PubMed]

64. de Oliveira Rodrigues, P.; Gurgel, L.V.A.; Pasquini, D.; Badotti, F.; Góes-Neto, A.; Baffi, M.A. Lignocellulose-degrading enzymes production by solid-state fermentation through fungal consortium among Ascomycetes and Basidiomycetes. Renew. Energy 2020, 145, 2683-2693. [CrossRef]

65. Crognale, S.; Pesciaroli, L.; Petruccioli, M.; D'Annibale, A. Phenoloxidase-producing halotolerant fungi from olive brine wastewater. Process Biochem. 2012, 47, 1433-1437. [CrossRef]

66. Dos Santos, T.C.; dos Santos Reis, N.; Silva, T.P.; Machado, F.D.P.P.; Bonomo, R.C.F.; Franco, M. Prickly palm cactus husk as a raw material for production of ligninolytic enzymes by Aspergillus niger. Food Sci. Biotechnol. 2016, 25, 205-211. [CrossRef] [PubMed] 